trans-2-pentene, 646-04-8; 1-hexene, 592-41-6; trans-2-hexene, 4050-45-7; trans-3-hexene, 13269-52-8; 1-heptene, 592-76-7; 2methylpropene, 115-11-7; 3-methyl-1-butene, 563-45-1; 2methyl-2-butene, 513-35-9; 2-methyl-1-pentene, 763-29-1; 3methyl-1-pentene, 760-20-3; 4-methyl-1-pentene, 691-37-2; 2 - methyl-2-pentene, 625-27-4; 3-methyl-2-pentene, 922-61-2; 4methyl-2-pentene, 4461-48-7; 2,3-dimethyl-1-butene, 563-78-0; 3,3-dimethyl-1-butene, 558-37-2; 2,3-dimethyl-2-butene, 563-79-1; cyclopentene, 142-29-0; cyclohexene, 110-83-8; 1-methylcyclohexene, 591-49-1; isobutene, 115-11-7.

\title{
Ortho-Chelated Arylrhodium(I) Complexes. X-ray Structure of $\mathrm{Rh}^{\mathrm{I}}\left[\mathrm{C}_{6} \mathrm{H}_{3}\left(\mathrm{CH}_{2} \mathrm{NMe}_{2}\right)_{2}-\mathrm{O}, \mathrm{O}^{\prime}-\mathrm{C}, \mathrm{N}\right](\mathrm{COD})$
}

\author{
Adolphus A. H. van der Zeijden, Gerard van Koten, ${ }^{*}$ and Richard A. Nordemann \\ Anorganisch Chemisch Laboratorium, University of Amsterdam, Nieuwe Achtergracht 166, \\ 1018 WV Amsterdam, The Netherlands \\ Biserka Kojič-Prodič and Anthony L. Spek \\ Vakgroep Algemene Chemie, Afdeling Kristal- en Structuurchemie, University of Utrecht, Padualaan 8 , \\ $3584 \mathrm{CH}$ Utrecht, The Netherlands
}

Received November 9, 1987

\begin{abstract}
The reaction of $\mathrm{Li}_{n}\left[\mathrm{C}_{6} \mathrm{H}_{3}\left(\mathrm{CH}_{2} \mathrm{NMe}_{2}\right)-o-\mathrm{R}-o^{\prime}\right]_{n}$ with $[\mathrm{RhCl} \text { (diene) }]_{2}$ yields the ortho-chelated arylrhodium(I) complexes $\mathrm{Rh}\left[\mathrm{C}_{6} \mathrm{H}_{3}\left(\mathrm{CH}_{2} \mathrm{NMe}_{2}\right)-o-\mathrm{R}-o^{\prime}\right]$ (diene) $\left(\mathrm{R}=\mathrm{CH}_{2} \mathrm{NMe}_{2}\right.$, diene = COD (1a) or NBD (1b); diene = $\mathrm{COD}, \mathrm{R}=\mathrm{Me}(2)$ or $\mathrm{H}(3))$. The solid-state structure of $1 \mathrm{a}$ was determined by a single-crystal X-ray diffraction study. $\mathrm{C}_{20} \mathrm{H}_{31} \mathrm{~N}_{2} \mathrm{Rh}$ : triclinic, space group $P \overline{1}$, with lattice parameters $a=10.169$ (1) $\AA, b=$ 13.036 (1) $\AA, c=14.688(2) \AA, \alpha=79.54(1)^{\circ}, \beta=77.04(1)^{\circ}, \gamma=79.53^{\circ} ; V=1845.6$ (4) $\AA^{3}, Z=4 ; D$ (calcd) $=1.448 \mathrm{~g} \mathrm{~cm}^{-3}$. Refinement with 4696 observed reflections converged at $R=0.0395$. The structure of la consists of a rhodium(I) center that has a square-planar coordination comprising the two double bonds of $\mathrm{COD}$ and $\mathrm{a} \mathrm{C}$ atom and one of the $\mathrm{N}$ atoms of the monoanionic aryl ligand. In solution compounds 1 and 2 exhibit dynamic behavior which involves a reversible dissociation of the $\mathrm{Rh}-\mathrm{N}$ bond and rotation of the aryl moiety around $\mathrm{Rh}-\mathrm{C}$. This process, which generates a highly unsaturated $\mathrm{T}$-shaped 14 electron species, is accompanied by the relief of steric repulsions within the complex. Complex 1 reacts with a range of electrophilic reagents leading to $\mathrm{Rh}-\mathrm{C}$ bond breakage $(\mathrm{HX}, \mathrm{X}=\mathrm{acac}, \mathrm{Cl}, \mathrm{Br}, \mathrm{OAc}, \mathrm{OH}, \mathrm{OMe}, \mathrm{L}$-alanyl; $\mathrm{MX}_{n} \mathrm{~L}_{\mathrm{m}}, \mathrm{SnMe}_{2} \mathrm{Br}_{2}, \mathrm{NiBr}_{2}\left(\mathrm{PBu}_{3}\right)_{2}, \mathrm{ZrCl}_{4}, \mathrm{PdCl}_{2}(\mathrm{NCPh})_{2}, \mathrm{HgCl}_{2}, \mathrm{PtBr}_{2}(\mathrm{COD})$, and [IrCl(COD) $\left.]_{2}\right)$. A redox reaction of 1 with $\mathrm{AgX}\left(\mathrm{X}=\mathrm{OAc}, \mathrm{NO}_{3}\right)$ leads to the formation of $\mathrm{Rh}^{\mathrm{III}} \mathrm{X}_{2}\left[\mathrm{C}_{6} \mathrm{H}_{3}\left(\mathrm{CH}_{2} \mathrm{NMe}_{2}\right)_{2}-0, O^{\prime}\right]\left(\mathrm{H}_{2} \mathrm{O}\right)$.
\end{abstract}

\section{Introduction}

Recently we reported on the syntheses of $\mathrm{Rh}^{\mathrm{III}} \mathrm{Cl}_{2}$ $\left[\mathrm{C}_{6} \mathrm{H}_{3}\left(\mathrm{CH}_{2} \mathrm{NMe}_{2}\right)_{2}-0,0^{\prime}\right]\left(\mathrm{H}_{2} \mathrm{O}\right)$ via direct metalation of $m-\left(\mathrm{Me}_{2} \mathrm{NCH}_{2}\right)_{2} \mathrm{C}_{6} \mathrm{H}_{4}$ with $\mathrm{RhCl}_{3}\left(\mathrm{H}_{2} \mathrm{O}\right)_{3}$ (eq 1). ${ }^{1 v}$ The high

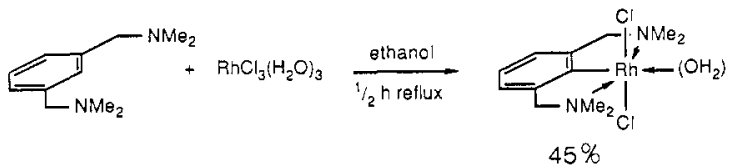

$45 \%$

stability of this organometallic complex and its derivatives shows the stabilizing influence that the "built-in" ligands in the organo group have on the metal-carbon bond. In the special case of bis-ortho chelation, a terdentate monoanionic aryl ligand like $\left[\mathrm{C}_{6} \mathrm{H}_{3}\left(\mathrm{CH}_{2} \mathrm{NMe}_{2}\right)_{2}-0,0^{\prime}\right]$ encapsulates the complexed metal to some extent but still leaves enough distinctly positioned sites for the resulting complex to serve as a model compound for the study of elementary reaction processes. In this respect the use of organo, but also nonorgano, ${ }^{2}$ terdentate ligands has been extensively exploited by us ${ }^{1}$ and others ${ }^{3-6}$ and has produced many unprecedented results. The chemistry of nickel(II) and platinum(II) $\left[\mathrm{C}_{6} \mathrm{H}_{3}\left(\mathrm{CH}_{2} \mathrm{NMe}_{2}\right)_{2^{-}}\right.$o, $\left.0^{\prime}\right]$ complexes has greatly improved our understanding of the elementary steps in electron-transfer processes between $\mathrm{d}^{8}$ metal complexes

\footnotetext{
* To whom correspondence should be addressed at the Laboratory of Organic Chemistry, Department of Metal Mediated Synthesis, University of Utrecht, Padualaan 8, $3584 \mathrm{CH}$ Utrecht, The Netherlands.
}

and electrophiles like alkyl halides and halogens. ${ }^{1}$ These results prompted us to also develop the chemistry of

(1) (a) van Koten, G.; Leusink, A. J.; Noltes, J. G. J. Chem. Soc., Chem. Commun. 1970, 1107. (b) van Koten, G.; Jastrzebski, J. T. B. H.; Noltes, J. G.; Spek, A. L.; Schoone, J. C. J. Organomet. Chem. 1978, 148, 233. (c) van der Ploeg, A. F. M. J.; van Koten, G.; Vrieze, K.; Spek, A. L. Inorg. Chem. 1982, 21, 2014. (d) van der Ploeg, A. F. M. J.; van Koten, G.; Vrieze, K. Inorg. Chem. 1982, 21, 2026. (e) van der Ploeg, A. F. M. J.; van Koten, G.; Vrieze, K. J. Organomet. Chem. 1982, 226, 93. (f) van der Ploeg, A. F. M. J.; van Koten, G.; Vrieze, K. Inorg. Chim. Acta 1982, 58, 35. (g) van der Ploeg, A. F. M. J.; van Koten, G.; Vrieze, K. J. Organomet. Chem. 1981, 222, 155. (h) Grove, D. M.; van Koten, G.; Ubbels, H. J. C.; Spek, A. L. J. Am. Chem. Soc. 1982, 104, 4285. (i) Grove, D. M.; van Koten, G.; Louwen, J. N.; Noltes, J. G.; Spek, A. L.; Ubbels, H. J. C. J. Am. Chem. Soc. 1982, 104, 6609. (j) van der Ploeg, A. F. M. J.; van Koten, G.; Vrieze, K.; Spek, A. L.; Duisenberg, A. J. M. Organometallics 1982, 1, 1066. (k) Grove, D. M.; van Koten, G.; Ubbels, H. J. C. Organometallics 1982, 1, 1366. (1) Jastrzebski, J. T. B. H.; van Koten, G.; Konijn, M.; Stam, C. H. J. Am. Chem. Soc. 1982, 104, 5490. (m) Grove, D. M.; van Koten, G.; Zoet, R.; Murrall, N. W.; Welch, A. J. J. Am. Chem. Soc. 1983, 105, 1379. (n) Grove, D. M.; van Koten, G.; Ubbels, H. J. C.; Zoet, R.; Spek, A. L. Organometallics 1984, 3, 1003. (o) Grove, D. M.; van Koten, G.; Mul, W. P.; van der Zeijden, A. A. H.; Terheijden, J.; Zoutberg, M. C.; Stam, C. H. Organometallics 1986, 5, 322. (p) Terheijden, J.; van Koten, G.; de Booijs, J. L.; Ubbels, H. J. C.; Stam, C. H. Organometallics 1983, 2, 1882. (q) Terheijden, J.; van Koten, G.; Muller, F.; Grove, D. M.; Vrieze, K.; Nielsen, E.; Stam, C. H. J. Organomet. Chem. 1986, 315, 401. (r) Terheijden, J.; van Koten, G.; Mul, W. P.; Stufkens, D. J.; Muller, F.; Stam, C. H. Organometallics 1986, 5, 519. (s) Terheijden, J.; van Koten, G.; Vinke, I. C.; Spek, A. L. J. Am. Chem. Soc. 1985, 107, 2891. (t) de Koster, A.; Kanters, J. A.; Spek, A. L.; van der Zeijden, A. A. H.; van Koten, G.; Vrieze, K. Acta Crystallogr., Sect. C: Cryst. Struct. Commun. 1985, C41, 893. (u) van der Zeijden, A. A. H.; van Koten, G. Inorg. Chem. 1986, 25, 4723. (v) van der Zeijden, A. A. H.; van Koten, G.; Luijk, R.; Slob, C.; Krabbendam, H.; Spek, A. L. Organometallics 1988, 27, 1014. (w) van Beek, J. A. M.; van Koten, G.; Smeets, W. J. J.; Spek, A. L. J. Am. Chem. Soc. 1986, 108, 5010. 
analogous rhodium(I) and iridium(I) species having aryl ligands that are either mono- or bis-ortho-chelated by nitrogen donor groups. Since soft phosphorus ligands have usually been used in combination with these $d^{8}$ centers, the choice of hard nitrogen ligands may appear at first sight to be ill-advised. However, we have shown that in the $\mathrm{d}^{8}$ metal complexes $\mathrm{Ni}^{\mathrm{I} X}\left[\mathrm{C}_{6} \mathrm{H}_{3}\left(\mathrm{CH}_{2} \mathrm{NMe}_{2}\right)_{2^{-}} \mathrm{O}, \mathrm{o}^{\prime}\right]$ and $\mathrm{Pt}{ }^{\mathrm{IIX}}\left[\mathrm{C}_{6} \mathrm{H}_{3}\left(\mathrm{CH}_{2} \mathrm{NMe}_{2}\right)_{2}-\mathrm{O}, \mathrm{o}^{\prime}\right]$ full coordination of the terdentate aryl ligand greatly enhances the nucleophilicity of these metal centers. The result of this is that, first, complexes involving coordination of electrophiles (through interaction of empty low-lying orbitals with the filled $d_{z^{2}}$ metal orbital) become stable and can be isolated, e.g. $\mathrm{Pt}^{\mathrm{II} X}\left[\mathrm{C}_{6} \mathrm{H}_{3}\left(\mathrm{CH}_{2} \mathrm{NMe}_{2}\right)_{2}-0,0^{\prime}\right]\left(\eta^{1}-\mathrm{SO}_{2}\right)^{1 \mathrm{rr}}$ and $\mathrm{Pt}^{\mathrm{II}} \mathrm{I}\left[\mathrm{C}_{6} \mathrm{H}_{3}\right.$ $\left.\left(\mathrm{CH}_{2} \mathrm{NMe}_{2}\right)_{2}-0,0^{\prime}\right]\left(\eta^{1}-\mathrm{I}_{2}\right),{ }^{1, w}$ and, second, one- and twoelectron transfer (with $\mathrm{Cu}^{\mathrm{II}} \mathrm{X}_{2}$ or halogens) leads to oxidized products, e.g. $\mathrm{Ni}^{\mathrm{III}} \mathrm{X}_{2}\left[\mathrm{C}_{6} \mathrm{H}_{3}\left(\mathrm{CH}_{2} \mathrm{NMe}_{2}\right)_{2}-0,0^{\prime}\right]^{1 \mathrm{~m}}$ and $\mathrm{Pt}^{\mathrm{IV}} \mathrm{X}_{3}\left[\mathrm{C}_{6} \mathrm{H}_{3}\left(\mathrm{CH}_{2} \mathrm{NMe}_{2}\right)_{2^{-0}, 0^{\prime}}\right](\mathrm{X}=\mathrm{Cl}, \mathrm{Br}){ }^{. \mathrm{p}}$ Since rhodium(I) has a higher basicity than either nickel(II) or platinum(II), the use of a hard nitrogen donor ligand may destabilize this low oxidation state. This deduction is confirmed by the direct metalation reaction in eq 1 which actually leads to a $d^{6} \mathrm{Rh}^{\mathrm{III}}$ complex rather than a $\mathrm{d}^{8} \mathrm{Rh}^{\mathrm{I}}$ species. Consequently, we set out to synthesize suitable rhodium(I) $\left[\mathrm{C}_{6} \mathrm{H}_{3}\left(\mathrm{CH}_{2} \mathrm{NMe}_{2}\right)_{2}-0,0^{\prime}\right]$ precursors so that both the coordination of the aryl ligand to rhodium(I) and the reactivity of the resulting complexes toward electrophiles could be studied. In addition, arylrhodium(I) complexes of the monoamine anions $\left[\mathrm{C}_{6} \mathrm{H}_{3}\left(\mathrm{CH}_{2} \mathrm{NMe}_{2}\right)-0-\mathrm{Me}-\mathrm{o}^{\prime}\right]$ and $\left[\mathrm{C}_{6} \mathrm{H}_{4}\left(\mathrm{CH}_{2} \mathrm{NMe}_{2}\right)-0\right]$ were synthesized in order to study the influence of the ortho'-positioned substituent (either $\mathrm{Me}$ or $\mathrm{H}$ ) on complex stability. This paper presents our results on the synthesis, structure, and reactivity of $\mathrm{RhR}$ (diene) $\left[\mathrm{R}=\mathrm{C}_{6} \mathrm{H}_{3}\left(\mathrm{CH}_{2} \mathrm{NMe}_{2}\right)_{2}-0,0^{\prime}\right.$, diene = $\mathrm{COD}$ (1,5-cyclooctadiene) (1a) or NBD (norbornadiene) (1b); diene = $\mathrm{COD}, \mathrm{R}=\mathrm{C}_{6} \mathrm{H}_{3}\left(\mathrm{CH}_{2} \mathrm{NMe}_{2}\right)-0-\mathrm{Me}-0^{\prime}(2)$ or $\mathrm{C}_{6} \mathrm{H}_{4^{-}}$ $\left.\left(\mathrm{CH}_{2} \mathrm{NMe}_{2}\right)-o(3)\right]$.

\section{Experimental Section}

General Data. Gaseous reactants $\left(\mathrm{HCl}, \mathrm{HBr}, \mathrm{O}_{2}\right.$, and $\mathrm{H}_{2}$ ) were bubbled through sulfuric acid prior to use. All reactions involving

(2) (a) Fryzuk, M. D.; MacNeil, P. A. Organometallics 1983, 2, 355. (b) Fryzuk, M. D.; MacNeil, P. A. Organometallics 1983, 2, 682. (c) Fryzuk M. D.: MacNeil, P. A. Rettig, S. J. Organometallics 1985, 4, 1145. (d) Fryzuk, M. D.; MacNeil, P. A.; Rettig, S. J. J. Am. Chem. Soc. 1985, 107 6708. (e) Fryzuk, M. D.; MacNeil, P. A.; Rettig, S. J. Organometallics 1986, 5, 2469. (f) Fryzuk, M. D.; MacNeil, P. A.; Rettig, S. J. J. Am. Chem. Soc. 1987, 109, 2803. (g) Fanizzi, F. P.; Natile, G.; Lanfranchi, M. Tiripicchio, A.; Clark, R. J. H.; Kurmoo, M. J. Chem. Soc., Dalton Trans. 1986, 273. (h) Lavery, A.; Nelson, S. M. J. Chem. Soc., Dalton Trans. $1985,1053$.

(3) (a) Canty, A. J.; Minchin, N. J.; Engelhardt, L. M.; White, A. H. J. Chem. Soc., Dalton Trans. 1987, 1477. (b) Canty, A. J.; Minchin, N. J.; Skelton, B. W.; White, A. H. J. Chem. Soc., Dalton Trans. 1986, in press.

(4) (a) Moulton, C. J.; Shaw, B. L. J. Chem. Soc., Dalton Trans. 1976 1020. (b) Empsall, H. D.; Hyde, E. M.; Markham, R.; McDonald, W. S.; Norton, M. C.; Shaw, B. L.; Weeks, B. J. Chem. Soc., Chem. Commun. 1977, 589. (c) Crocker, C.; Errington, R. J.; McDonald, W. S.; Odell, K J.; Shaw, B. L.; Goodfellow, R. J. J. Chem. Soc., Chem. Commun. 1979, 498. (d) Errington, J.; McDonald, W. S.; Shaw, B. L. J. Chem. Soc. Dalton Trans. 1980, 2312. (e) Crocker, C.; Errington, J.; Markham, R.; Moulton, C. J.; Odell, K. J.; Shaw, B. L. J. Chem. Soc., Dalton Trans. 1980, 4373. (f) Crocker, C.; Empsall, H. D.; Errington, R. J.; Hyde, E. M. McDonald, W. S.; Markham, R.; Norton, M. C.; Shaw, B. L.; Weeks, B. J. Chem. Soc., Dalton Trans. 1982, 1217. (g) Briggs, J. R.; Constable, A. G.; McDonald, W. S.; Shaw, B. L. J. Chem. Soc., Dalton Trans. 1982 1225. (h) Errington, R. J.; McDonald, W. S.; Shaw, B. L. J. Chem. Soc., Dalton Trans. 1982, 1829.

(5) (a) Creaser, C. S.; Kaska, W. C. Inorg. Chim. Acta 1978, 30, L325. (b) Nemeh, S.; Jensen, C.; Binamira-Soriage, E., Kaska, W. C. Organometallics $1983,2,1442$.

(6) (a) Rimml, H; Venanzi, L. M. J. Organomet. Chem. 1983, 259, C6. (b) Rimml, H.; Venanzi, L. M. J. Organomet. Chem. 1984, 260 , C52.
rhodium(I) complexes were performed under an atmosphere of dry nitrogen using Schlenk techniques. Solvents were carefully dried and distilled prior to use. Reactions were carried out at room temperature unless stated otherwise. ${ }^{1} \mathrm{H}$ NMR spectra were recorded on either a Varian T60 or a Bruker WM250 spectrometer; the latter was also used for ${ }^{13} \mathrm{C}$ NMR measurements. Elemental analyses were carried out by the Analytical Department of the Institute for Applied Chemistry, TNO, Zeist, The Netherlands. Field desorption (FD) mass spectra were obtained with a Varian MAT711 double focussing mass spectrometer and were performed by the Organic Department of the University of Amsterdam (Prof. N. M. M. Nibbering).

Synthesis of $\mathrm{Rh}\left[\mathrm{C}_{6} \mathrm{H}_{3}\left(\mathrm{CH}_{2} \mathrm{NMe}_{2}\right)_{2}-\boldsymbol{o}, o^{\prime}\right]$ (COD) (1a). A solution of $\mathrm{Li}_{2}\left[\mathrm{C}_{6} \mathrm{H}_{3}\left(\mathrm{CH}_{2} \mathrm{NMe}_{2}\right)_{2}-0, o^{\prime}\right]_{2}$ in diethyl ether $(10 \mathrm{~mL})$, prepared from $0,0^{\prime}-\left(\mathrm{Me}_{2} \mathrm{NCH}_{2}\right)_{2} \mathrm{C}_{6} \mathrm{H}_{3} \mathrm{Br}(3.6 \mathrm{~g}, 13 \mathrm{mmol})$ and lithium shavings, ${ }^{1 \mathrm{i}}$ was added to a suspension of $[\mathrm{RhCl}(\mathrm{COD})]_{2}{ }^{7 \mathrm{a}}$ $(3.2 \mathrm{~g}, 6.5 \mathrm{mmol})$ in diethyl ether $(30 \mathrm{~mL})$. After the mixture was stirred for $1 \mathrm{~h}$, the solvent was removed in vacuo, resulting in a foamy, yellow residue, which was extracted several times with warm hexane (150 $\mathrm{mL}$ in total), and the solution subsequently filtered. The filtrate was evaporated to dryness and the residue washed twice with cold $\left(-30^{\circ} \mathrm{C}\right)$ pentane $(10 \mathrm{~mL})$ affording orange 1a in $90 \%$ yield. Anal. Calcd for $\mathrm{C}_{20} \mathrm{H}_{31} \mathrm{~N}_{2} \mathrm{Rh}$ : C, $59.70 ; \mathrm{H}, 7.77$; $\mathrm{N}, 6.96$. Found: $\mathrm{C}, 59.39 ; \mathrm{H}, 7.93 ; \mathrm{N}, 6.92$. Crystals of the rhodium compound suitable for $\mathrm{X}$-ray diffraction were grown by cooling a saturated solution of $1 \mathrm{a}$ in hexane from $60-25^{\circ} \mathrm{C}$ within a few hours.

Synthesis of $\mathrm{Rh}\left[\mathrm{C}_{6} \mathrm{H}_{3}\left(\mathrm{CH}_{2} \mathrm{NMe}_{2}\right)_{2}-o, o^{\prime}\right]$ (NBD) (1b). A solution of $\mathrm{Li}_{2}\left[\mathrm{C}_{6} \mathrm{H}_{3}\left(\mathrm{CH}_{2} \mathrm{NMe}_{2}\right)_{2}-o, o^{\prime}\right]_{2}$ in diethyl ether $(10 \mathrm{~mL})$, prepared from $0,0^{\prime}-\left(\mathrm{Me}_{2} \mathrm{NCH}_{2}\right)_{2} \mathrm{C}_{6} \mathrm{H}_{3} \mathrm{Br}(1.2 \mathrm{~g}, 4.3 \mathrm{mmol})$ and lithium shavings, ${ }^{1 \mathrm{i}}$ was added to a stirred suspension of [RhCl$(\mathrm{NBD})]_{2}{ }^{7 \mathrm{~b}}(0.81 \mathrm{~g}, 1.8 \mathrm{mmol})$ in diethyl ether. After $1 \mathrm{~h}$ the solvent was removed in vacuo. The resulting residue was extracted with benzene $(35 \mathrm{~mL})$ and the solution filtered. The filtrate was evaporated to dryness and the residue washed several times with cold pentane $(5 \mathrm{~mL})$ yielding, after drying, orange $1 \mathrm{~b}(0.80 \mathrm{~g}, 60 \%)$. Anal. Calcd for $\mathrm{C}_{19} \mathrm{H}_{27} \mathrm{~N}_{2} \mathrm{Rh}$ : C, 59.07; H, 7.04; N, 7.25. Found: C, 58.08; H, 7.15; N, 7.03.

Synthesis of $\mathrm{Rh}\left[\mathrm{C}_{6} \mathrm{H}_{3}\left(\mathrm{CH}_{2} \mathrm{NMe}_{2}\right)-o-\mathrm{Me}-o^{\prime}\right](\mathrm{COD})$ (2). To a solution of $o-\left(\mathrm{Me}_{2} \mathrm{NCH}_{2}\right)-0^{\prime}-(\mathrm{Me}) \mathrm{C}_{6} \mathrm{H}_{3} \mathrm{Br}^{8}(0.52 \mathrm{~g}, 2.3 \mathrm{mmol})$ in benzene $(5 \mathrm{~mL})$ was added 1 equiv of $n$-BuLi in hexane. The resulting orange suspension was added in $2 \mathrm{~h}$ to a solution of $[\mathrm{RhCl}(\mathrm{COD})]_{2}^{7 \mathrm{a}}(0.50 \mathrm{~g}, 1.0 \mathrm{mmol})$ in benzene $(10 \mathrm{~mL})$. The reaction mixture was stirred for $1 \mathrm{~h}$ and filtered. The filtrate was evaporated to dryness and the residue washed with a little pentane, affording orange 2 in $85 \%$ yield.

Synthesis of $\mathrm{Rh}\left[\mathrm{C}_{6} \mathrm{H}_{4}\left(\mathrm{CH}_{2} \mathrm{NMe}_{2}\right)-o\right](\mathrm{COD})$ (3). To a solution of $[\mathrm{RhCl}(\mathrm{COD})]_{2}^{7 \mathrm{a}}(1.80 \mathrm{~g}, 3.7 \mathrm{mmol})$ in benzene $(10 \mathrm{~mL})$ was added in $1 \mathrm{~h}$ a suspension of $\mathrm{Li}\left[\mathrm{C}_{6} \mathrm{H}_{4}\left(\mathrm{CH}_{2} \mathrm{NMe}_{2}\right)-0\right]^{7 \mathrm{e}}(1.05$ $\mathrm{g}, 7.4 \mathrm{mmol})$ in benzene $(10 \mathrm{~mL})$. Workup as described for 2 afforded orange 3 in $85 \%$ yield.

Reaction of $1 \mathrm{a}$ with $\mathrm{HCl}$. Dry gaseous $\mathrm{HCl}$ was bubbled for $1 \mathrm{~min}$ through a solution of $1 \mathrm{a}(51 \mathrm{mg}, 0.127 \mathrm{mmol})$ in benzene $(3 \mathrm{~mL})$. Water was added $(3 \mathrm{~mL})$, and the two layers were separated. Evaporation of the benzene layer to dryness afforded a virtually quantitative yield of pure $[\mathrm{RhCl}(\mathrm{COD})]_{2}\left({ }^{1} \mathrm{H} \mathrm{NMR}\right.$ $\left(\mathrm{CDCl}_{3}\right) \delta 1.75(\mathrm{~m}, 8 \mathrm{H}), 2.5(\mathrm{~m}, 8 \mathrm{H}), 4.21(\mathrm{~m}, 8 \mathrm{H})$; ref $9, \delta 1.77$, 2.55 , and 4.27 , respectively). From the water layer, by evaporation of the solvent, was obtained a quantitative yield of the ammonium salt $\left[m-\left(\mathrm{Me}_{2}(\mathrm{H}) \mathrm{NCH}_{2}\right)_{2} \mathrm{C}_{6} \mathrm{H}_{4}\right] \mathrm{Cl}_{2}\left({ }^{1} \mathrm{H} \mathrm{NMR}\left(\mathrm{CD}_{3} \mathrm{OD}\right) \delta 2.91(12\right.$ $\mathrm{H}), 4.40(4 \mathrm{H}), 7.65(\mathrm{~m}, 4 \mathrm{H})$; an authentic sample isolated from the reaction of $m \cdot\left(\mathrm{Me}_{2} \mathrm{NCH}_{2}\right)_{2} \mathrm{C}_{6} \mathrm{H}_{4}$ with hydrochloric acid gave $\delta 2.88,4.41$, and 7.65 , respectively).

(7) (a) Chatt, J.; Venanzi, L. M. J. Chem. Soc. 1957, 4735. (b) Abel, E. W.; Bennett, M. A.; Wilkinson, G. J. Chem. Soc. 1959, 3178. (c) Manzer, L. E. J. Am. Chem. Soc. 1978, 100, 8068.

(8) 1-Methyl-2-bromo-3-[(dimethylamino)methyl]benzene was synthesized from 1-methyl-2-bromo-3-(bromomethyl)benzene and 2 equiv of dimethylamine in dry benzene: yield $65 \%$; bp $100^{\circ} \mathrm{C}$ at $0.2 \mathrm{mmHg} ;{ }^{1} \mathrm{H}$ NMR $\left(\mathrm{CDCl}_{3}\right) \delta 2.29(\mathrm{NMe}, 6 \mathrm{H}), 2.40(\mathrm{Me}, 3 \mathrm{H}), 3.49\left(\mathrm{NCH}_{2}, 2 \mathrm{H}\right), 7.05$ (aryl H m $3 \mathrm{H}) \cdot{ }^{13} \mathrm{C}$ NMR $(\mathrm{CDCl}) \delta 23.5(\mathrm{Me}), 45.3(\mathrm{NMe}), 63.7\left(\mathrm{NCH}_{2}\right)$ 127.0 (aryl C1), 138.1, 138.4 (aryl C2/C6), 127.9, 129.1 (aryl C3/C5), 126.3 (aryl C4). 1-Methyl-2-bromo-3-(bromomethyl) benzene was obtained from 1,3-dimethyl-2-bromobenzene and 1 equiv of NBS in $\mathrm{CCl}_{4}$ : ${ }^{1} \mathrm{H}$ NMR $\left(\mathrm{CCl}_{4}\right) \delta 2.52(\mathrm{Me}), 4.69\left(\mathrm{CH}_{2}\right), 7.29$ (aryl).

(9) Robinson, S. D.; Shaw, B. L. J. Chem. Soc. 1965, 4997. 
Reaction of 1a with HBr. Dry gaseous $\mathrm{HBr}$ was bubbled for $5 \mathrm{~min}$ through a solution of $1 \mathrm{a}(0.30 \mathrm{~g}, 0.75 \mathrm{mmol})$ in benzene (10 $\mathrm{mL}$ ). The dark red mixture was filtered and the solid extracted with benzene. The white solid isolated in this way was identified as $\left[m-\left(\mathrm{Me}_{2}(\mathrm{H}) \mathrm{NCH}_{2}\right)_{2} \mathrm{C}_{6} \mathrm{H}_{4}\right] \mathrm{Br}_{2}\left(100 \%\right.$ yield; ${ }^{1} \mathrm{H}$ NMR $\left(\mathrm{CD}_{3} \mathrm{OD}\right)$ $\delta 2.91(12 \mathrm{H}), 4.45(4 \mathrm{H}), 7.65(\mathrm{~m}, 4 \mathrm{H}))$. The combined benzene filtrates and extracts were evaporated to dryness and the residue washed with pentane, resulting in a quantitative yield of orange brown $[\mathrm{RhBr}(\mathrm{COD})]_{2}\left({ }^{1} \mathrm{H} \mathrm{NMR}\left(\mathrm{CDCl}_{3}\right) \delta 1.65(\mathrm{~m}, 8 \mathrm{H}), 2.4(\mathrm{~m}\right.$, $8 \mathrm{H}), 4.40(\mathrm{~m}, 8 \mathrm{H})$; calcd mol wt for $\mathrm{C}_{16} \mathrm{H}_{24} \mathrm{Br}_{2} \mathrm{Rh}_{2} 581.99$; $\mathrm{FD}$ mass, $m / e$ 582).

Reaction of 1a with Acetic Acid. To a solution of 1a 63 $\mathrm{mg}, 0.157 \mathrm{mmol})$ in benzene $(3 \mathrm{~mL})$ was added HOAc $(0.1 \mathrm{~mL}$, excess). The clear yellow solution was stirred for $5 \mathrm{~min}$, after which water was added $(3 \mathrm{~mL})$. The two layers were separated and both evaporated to dryness. In this way the benzene extract afforded orange $[\mathrm{RhOAc}(\mathrm{COD})]_{2}\left(100 \%\right.$ yield; ${ }^{1} \mathrm{H} \mathrm{NMR}\left(\mathrm{CDCl}_{3}\right) \delta 1.75(6$ $\mathrm{H}), 1.9(\mathrm{~m}, 8 \mathrm{H}), 2.65(\mathrm{~m}, 8 \mathrm{H}), 4.09(\mathrm{~m}, 8 \mathrm{H}) ;$ ref $9, \delta 1.75,1.88$, $2.74,4.14$, respectively). The water extract afforded a colorless oil that was identified as $\left[m-\left(\mathrm{Me}_{2}(\mathrm{H}) \mathrm{NCH}_{2}\right)_{2} \mathrm{C}_{6} \mathrm{H}_{4}\right] \mathrm{OAc} \mathrm{C}_{2}(100 \%$ yield; ${ }^{1} \mathrm{H}$ NMR $\left(\mathrm{CD}_{3} \mathrm{OD}\right) \delta 1.96(6 \mathrm{H}), 2.70(12 \mathrm{H}), 4.12(4 \mathrm{H}), 7.51$ $(4 \mathrm{H})$ ).

Reaction of 1a with Methanol. To a solution of $1 \mathrm{a}(58 \mathrm{mg}$, $0.144 \mathrm{mmol}$ ) in benzene $(2 \mathrm{~mL})$ was added dry, nitrogen-saturated methanol $(0.1 \mathrm{~mL}$, excess). After being stirred for $30 \mathrm{~min}$, the clear yellow solution was evaporated to dryness. The residue was twice washed with pentane $(2 \mathrm{~mL})$ affording pale yellow $[\mathrm{RhOMe}(\mathrm{COD})]_{2}\left(28 \mathrm{mg}, 80 \% ;{ }^{1} \mathrm{H} \mathrm{NMR}\left(\mathrm{CDCl}_{3}\right) \delta 1.65(\mathrm{~m}, 8 \mathrm{H})\right.$, $2.4(\mathrm{~m}, 8 \mathrm{H}), 2.66(6 \mathrm{H}), 3.53(\mathrm{~m}, 8 \mathrm{H}) ;$ ref $10, \delta 1.63,2.47,2.67$, and 3.55 , respectively). The combined pentane washings, evaporated to dryness, afforded $m-\left(\mathrm{Me}_{2} \mathrm{NCH}_{2}\right)_{2} \mathrm{C}_{6} \mathrm{H}_{4}$ contaminated with a small amount of $[\mathrm{RhOMe}(\mathrm{COD})]_{2}$.

Reaction of $1 \mathrm{a}$ with Acetylacetone. The reaction of $1 \mathrm{a}$ (38 $\mathrm{mg}, 0.095 \mathrm{mmol}$ ) and 1 equiv of Hacac in benzene $(2 \mathrm{~mL})$ resulted in a clear yellow solution within $1 \mathrm{~min}$. The mixture was found to contain equimolar amounts of $\mathrm{Rh}(\mathrm{acac})(\mathrm{COD})$ and $\mathrm{m}$ $\left(\mathrm{Me}_{2} \mathrm{NCH}_{2}\right)_{2} \mathrm{C}_{6} \mathrm{H}_{4}$. Due to similar solubilities these products could not be separated and isolated. The ${ }^{1} \mathrm{H}$ NMR spectra of both the reaction mixture and, after evaporation of the solvent, the residue in $\mathrm{CDCl}_{3}$ confirmed the identity of the rhodium product $\left({ }^{1} \mathrm{H}\right.$ NMR $\left(\mathrm{CDCl}_{3}\right) \delta 1.92(6 \mathrm{H}), 2.2(\mathrm{~m}, 8 \mathrm{H}), 4.04(\mathrm{~m}, 4 \mathrm{H}), 5.28(1 \mathrm{H})$; ref $9, \delta 1.92,2.2,4.14$, and 5.35 , respectively).

Reaction of 1a with Water. A solution of 1a $(85 \mathrm{mg}, 0.211$ $\mathrm{mmol}$ ) was stirred for $30 \mathrm{~min}$ in a nitrogen-saturated mixture of acetone $(3 \mathrm{~mL}$ ) and water (ca. $0.3 \mathrm{~mL}$ ). The light yellow suspension produced in this way was evaporated to dryness and the residue washed with pentane $(3 \times 3 \mathrm{~mL})$. This afforded pure $[\mathrm{RhOH}(\mathrm{COD})]_{2}\left(100 \%\right.$ yield; ${ }^{1} \mathrm{H}$ NMR $\left(\mathrm{CDCl}_{3}\right) \delta 1.65(\mathrm{~m}, 8 \mathrm{H})$, $2.45(\mathrm{~m}, 8 \mathrm{H}), 3.74(8 \mathrm{H})$; ref $10, \delta 1.67,2.45$, and 3.82 , respectively). The combined pentane washings were evaporated to dryness affording $m$ - $\left(\mathrm{Me}_{2} \mathrm{NCH}_{2}\right)_{2} \mathrm{C}_{6} \mathrm{H}_{4}(35 \mathrm{mg}, 90 \%)$.

Reaction of $1 \mathrm{a}$ with L-Alanine. A solution of $1 \mathrm{a}(139 \mathrm{mg}$ $0.35 \mathrm{mmol})$ in benzene $(5 \mathrm{~mL})$ and L-alanine $(90 \mathrm{mg}, 1.0 \mathrm{mmol})$ was stirred for $3 \mathrm{~h}$ at $65^{\circ} \mathrm{C}$. Benzene was then removed in vacuo and the residue extracted with acetone. After filtration the extract was evaporated to dryness. The residue was washed twice with diethyl ether $(10 \mathrm{~mL})$, yielding a yellow powder $(69 \mathrm{mg}, 67 \%)$, which was identified as $\left[\mathrm{Rh}(\mathrm{L} \text {-alanyl)(COD) }]_{2}\right.$ by FD mass (calcd mol wt for $\mathrm{C}_{22} \mathrm{H}_{36} \mathrm{~N}_{2} \mathrm{O}_{4} \mathrm{Rh}_{2} \mathrm{~m} / e$ 598.35; found $\mathrm{m} / e$ 598) and ${ }^{1} \mathrm{H}$ NMR spectroscopy $\left(\left(\mathrm{CD}_{3} \mathrm{OD}\right) \delta 1.38[\mathrm{~d}(7 \mathrm{~Hz}), 6 \mathrm{H}], 1.9(\mathrm{~m}, 8 \mathrm{H})\right.$, $2.55(\mathrm{~m}, 8 \mathrm{H}), 2.7[\mathrm{q}(7 \mathrm{~Hz}), 2 \mathrm{H}), 4.06(\mathrm{~m}, 8 \mathrm{H}))$.

Attempted Reaction of $1 \mathrm{a}$ with $\mathrm{Ph}_{3} \mathrm{COH}$ and $\mathrm{Et}_{2} \mathrm{NH}$. A solution of $1 \mathrm{a}$ in benzene containing an excess of nitrogen-flushed $\mathrm{Ph}_{3} \mathrm{COH}$ or $\mathrm{Et}_{2} \mathrm{NH}$ was refluxed for $1 \mathrm{~h}$. Only starting products were identified.

Reaction of 1a with $\mathrm{SnMe}_{3} \mathrm{Br}_{2}$. To a solution of 1a $(88 \mathrm{mg}$, $0.21 \mathrm{mmol}$ ) in benzene $(4 \mathrm{~mL})$ was added solid $\mathrm{SnMe}_{2} \mathrm{Br}_{2}(66 \mathrm{mg}$, $0.21 \mathrm{mmol}$ ). After the mixture was stirred for $40 \mathrm{~min}$, water (3 $\mathrm{mL}$ ) was added to the reaction mixture. The two layers were separated and both evaporated to dryness. The benzene extract yielded quantitatively $[\mathrm{RhBr}(\mathrm{COD})]_{2}$ (calcd mol wt 581.99; FD mass, $m / e 582 ;{ }^{1} \mathrm{H}$ NMR $\left(\mathrm{C}_{6} \mathrm{D}_{6}\right) \delta 1.4(\mathrm{~m}, 8 \mathrm{H}), 2.1(\mathrm{~m}, 8 \mathrm{H}), 4.38$ $(\mathrm{m}, 8 \mathrm{H}))$. The water layer yielded quantitatively [SnMe

(10) Uson, R.; Oro, L. A. Inorg. Synth. 1985, 23, 126.

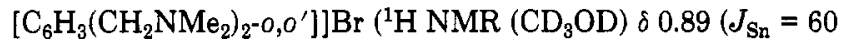
$\mathrm{Hz}, 6 \mathrm{H}), 2.56(12 \mathrm{H}), 3.87(4 \mathrm{H}), 7.2-7.65(\mathrm{~m}, 3 \mathrm{H})$; ref $1 \mathrm{~b}, \delta 0.84$ $(J=62 \mathrm{~Hz}), 2.50$, and 3.84 , respectively).

Reaction of la with Other Metal Salts. To a solution of 1a (ca. $0.2 \mathrm{mmol}$ ) in benzene or dichloromethane was added an equimolar amount of the appropriate metal salt $M X_{n} L_{m}$. In case of $\mathrm{NiBr}_{2}\left(\mathrm{PBu}_{3}\right)_{2}, \mathrm{ZrCl}_{4}, \mathrm{PdCl}_{2}(\mathrm{NCPh})_{2}, \mathrm{HgCl}_{2}$, and $[\mathrm{IrCl}(\mathrm{COD})]_{2}$ this resulted in an instant reaction. The reaction with $\mathrm{PtBr}_{2^{-}}$ (COD), monitored by ${ }^{1} \mathrm{H}$ NMR, required 1 -h reflux to reach completion. In all cases the reaction mixture consisted of $[\mathrm{RhX}(\mathrm{COD})]_{2}$ and $\mathrm{MX}_{n-1}\left[\mathrm{C}_{6} \mathrm{H}_{3}\left(\mathrm{CH}_{2} \mathrm{NMe}_{2}\right)_{2}-0,0^{\prime}\right]$ (and $m \mathrm{~L}$ ) in the molar ratio $1: 2(: \mathrm{m})$ as was deduced from ${ }^{1} \mathrm{H}$ NMR and FD mass spectroscopy. No other products were seen. Due to similar solubilities the metal-containing reaction products were not separated from each other.

$\mathrm{NiBr}\left[\mathrm{C}_{6} \mathrm{H}_{3}\left(\mathrm{CH}_{2} \mathrm{NMe}_{2}\right)_{2}-0,0^{\prime}\right]:{ }^{1} \mathrm{H} \mathrm{NMR}\left(\mathrm{C}_{6} \mathrm{D}_{6}\right) \delta 2.42(12 \mathrm{H})$, $3.04(4 \mathrm{H}), 7.1(3 \mathrm{H})$; ref $1 \mathrm{n}, \delta 2.52$ and 2.99 , respectively.

$\mathrm{ZrCl}_{3}\left[\mathrm{C}_{6} \mathrm{H}_{3}\left(\mathrm{CH}_{2} \mathrm{NMe}_{2}\right)_{2}-0,0^{\prime}\right]$ : ${ }^{1} \mathrm{H}$ NMR $\left(\mathrm{CH}_{2} \mathrm{Cl}_{2}\right) \delta 2.84(12 \mathrm{H})$, $4.19(4 \mathrm{H}), 7.0(\mathrm{~d}, 2 \mathrm{H}), 7.2(\mathrm{t}, 1 \mathrm{H}){ }^{11}$

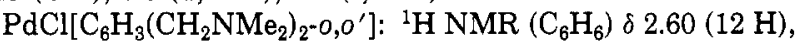
$3.29(4 \mathrm{H})$; ref $12, \delta 2.60$ and 3.27 , respectively; FD mass found $m / e 334\left[{ }^{106} \mathrm{Pd}^{37} \mathrm{Cl}\left[\mathrm{C}_{6} \mathrm{H}_{3}\left(\mathrm{CH}_{2} \mathrm{NMe}_{2}\right)_{2}-0,0^{\prime}\right]\right.$ and ${ }^{108} \mathrm{Pd}^{35} \mathrm{Cl}\left[\mathrm{C}_{6} \mathrm{H}_{3}\right.$ $\left.\left.\left(\mathrm{CH}_{2} \mathrm{NMe}_{2}\right)_{2}-0, o^{\prime}\right]\right]$ and $492\left[\mathrm{Rh}_{2}{ }^{35} \mathrm{Cl}_{2}(\mathrm{COD})_{2}\right]$.

$\mathrm{HgCl}\left[\mathrm{C}_{6} \mathrm{H}_{3}\left(\mathrm{CH}_{2} \mathrm{NMe}_{2}\right)_{2}-0, o^{\prime}\right]:{ }^{1} \mathrm{H}$ NMR $\left(\mathrm{C}_{6} \mathrm{H}_{6}\right) \delta 2.07(12 \mathrm{H})$, $3.07(12 \mathrm{H})$; ref $1 \mathrm{~g},\left(\mathrm{CDCl}_{3}\right) \delta 2.27$ and 3.33 , respectively; FD mass found $m / e \quad 428 \quad\left[{ }^{200} \mathrm{Hg}^{37} \mathrm{Cl}\left[\mathrm{C}_{6} \mathrm{H}_{3}\left(\mathrm{CH}_{2} \mathrm{NMe}_{2}\right)_{2}-0,0^{\prime}\right]\right.$ and $\left.{ }^{202} \mathrm{Hg}^{35} \mathrm{Cl}\left[\mathrm{C}_{6} \mathrm{H}_{3}\left(\mathrm{CH}_{2} \mathrm{NMe}_{2}\right)_{2}-0,0^{\prime}\right]\right]$.

$\mathrm{PtBr}\left[\mathrm{C}_{6} \mathrm{H}_{3}\left(\mathrm{CH}_{2} \mathrm{NMe}_{2}\right)_{2}=0,0^{\prime}\right]:{ }^{1} \mathrm{H}$ NMR $\left(\mathrm{C}_{6} \mathrm{H}_{6}\right) \delta 2.84\left(J_{\mathrm{Pt}}=\right.$ $38 \mathrm{~Hz}, 12 \mathrm{H}), 3.43\left(J_{\mathrm{Pt}}=46 \mathrm{~Hz}\right)$; ref $1 \mathrm{i}, \delta 2.90(J=38 \mathrm{~Hz})$ and $3.43(J=46 \mathrm{~Hz})$, respectively; $\mathrm{FD}$ mass found $m / e \quad 466$ [ ${ }^{194} \mathrm{Pt}^{81} \mathrm{Br}\left[\mathrm{C}_{6} \mathrm{H}_{3}\left(\mathrm{CH}_{2} \mathrm{NMe}_{2}\right)_{\left.2-0,0^{\prime}\right]}\right.$ and ${ }^{196} \mathrm{Pt}^{79} \mathrm{Br}\left[\mathrm{C}_{6} \mathrm{H}_{3}\right.$ $\left.\left.\left(\mathrm{CH}_{2} \mathrm{NMe}_{2}\right)_{2} \cdot 0,0^{\prime}\right]\right]$ and $582\left[\mathrm{Rh}_{2}{ }^{79} \mathrm{Br}^{81} \mathrm{Br}(\mathrm{COD})_{2}\right]$.

$\operatorname{Ir}\left[\mathrm{C}_{6} \mathrm{H}_{3}\left(\mathrm{CH}_{2} \mathrm{NMe}_{2}\right)_{2}-0,0^{\prime}\right](\mathrm{COD}):{ }^{1} \mathrm{H} \mathrm{NMR}\left(\mathrm{C}_{6} \mathrm{D}_{6}\right) \delta 2.11(12$ $\mathrm{H}), 3.62(4 \mathrm{H}), 3.45(2 \mathrm{H}), 5.14(2 \mathrm{H}) .^{13}$

No reaction was observed, even under reflux conditions, between la and $\mathrm{RhCl}_{3}, \mathrm{RhCl}_{3}\left(\mathrm{H}_{2} \mathrm{O}\right)_{3},[\mathrm{RhCl}(\mathrm{COD})]_{2}, \mathrm{IrCl}_{3}$, and $\mathrm{TaCl}_{5}$.

Reaction of la with Silver Salts. (a) Silver Acetate. To a solution of $1 \mathrm{a}(107 \mathrm{mg}, 0.266 \mathrm{mmol})$ in benzene $(5 \mathrm{~mL})$ was added $\mathrm{AgOAc}$ (105 mg, $0.63 \mathrm{mmol}$ ). Silver was deposited, and the reaction reached completion within $10 \mathrm{~min}$. The benzene was removed in vacuo and the residue extracted with wet acetone. The extract was filtered and evaporated to dryness. The residue was washed with pentane affording yellow $\mathrm{Rh}(\mathrm{OAc})_{2}\left[\mathrm{C}_{6} \mathrm{H}_{3}\right.$ $\left.\left(\mathrm{CH}_{2} \mathrm{NMe}_{2}\right)_{2} \cdot 0,0^{\prime}\right]\left(\mathrm{H}_{2} \mathrm{O}\right)(74 \mathrm{mg}, 70 \%)\left({ }^{1} \mathrm{H}\right.$ NMR (acetone- $\left.d_{6}\right) \delta$ $1.72(6 \mathrm{H}), 2.40(12 \mathrm{H}), 3.83(4 \mathrm{H}), 6.96(3 \mathrm{H})$; ref $1 \mathrm{v}, \delta 1.70,2.37$, 3.84 , and 7.00 , respectively).

(b) Silver Nitrate. The reaction of 1a with 2 equiv of $\mathrm{AgNO}_{3}$ proceeded similarly. $\mathrm{Rh}\left(\mathrm{NO}_{3}\right)_{2}\left[\mathrm{C}_{6} \mathrm{H}_{3}\left(\mathrm{CH}_{2} \mathrm{NMe}_{2}\right)_{2}-0,0^{\prime}\right]\left(\mathrm{H}_{2} \mathrm{O}\right)$ was isolated in $50 \%$ yield $\left({ }^{1} \mathrm{H} \mathrm{NMR}\right.$ (acetone- $\left.d_{6}\right) \delta 2.51(12 \mathrm{H}), 3.99$ $(4 \mathrm{H}), 7.04(3 \mathrm{H})$; ref $1 \mathrm{v}, \delta 2.51,4.01$, and 7.08 , respectively).

(c) Silver Chromate and Sulfate. Refluxing a solution of $1 \mathrm{a}$ in benzene containing a slight excess of either $\mathrm{Ag}_{2} \mathrm{CrO}_{4}$ or $\mathrm{Ag}_{2} \mathrm{SO}_{4}$ for $1 \mathrm{~h}$ gave no reaction; la was recovered unchanged.

Reaction of 1 with Hydrogen. Through a solution of $1 \mathrm{a}$ or 1b $(0.2 \mathrm{~g}, 0.5 \mathrm{mmol})$ in benzene $(5 \mathrm{~mL})$ was bubbled hydrogen for $5 \mathrm{~min}$. This resulted in the formation of a dark brown suspension. $m$ - $\left(\mathrm{Me}_{2} \mathrm{NCH}_{2}\right)_{2} \mathrm{C}_{6} \mathrm{H}_{4}$ and the reduced diolefin, i.e. norbornane or cyclooctane, were identified in solution. Evaporation of the volatile substances afforded a black sticky residue that was probably mainly metallic rhodium.

Structure Determination and Refinement of $\mathbf{R h}\left[\mathrm{C}_{6} \mathrm{H}_{3^{-}}\right.$ $\left.\left(\mathrm{CH}_{2} \mathrm{NMe}_{2}\right)_{2}-\boldsymbol{o}, o^{\prime}\right](\mathrm{COD})$ (1a). Crystal data and numerical details of the structure determination are listed in Table I. X-ray data were collected on an Enraf-Nonius CAD4F diffractometer for an orange crystal mounted in a Lindemann glass capillary.

(11) An impure compound that approximately analyzed as $\mathrm{ZrCl}_{3}$ $\left[\mathrm{C}_{6} \mathrm{H}_{3}\left(\mathrm{CH}_{2} \mathrm{NMe}_{2}\right)_{2}-0,0^{\prime}\right]$ and that had the same $\mathrm{NMR}$ characteristics was obtained from anhydrous $\mathrm{ZrCl}_{4}$ and $\mathrm{Li}_{2}\left[\mathrm{C}_{6} \mathrm{H}_{3}\left(\mathrm{CH}_{2} \mathrm{NMe}_{2}\right)_{2}-0,0^{\prime}\right]_{2}$ in diethyl ether: van der Zeijden, A. A. H.; van Koten, G., unpublished results. 1i,q.

12) Wissing, E.; van Beek, J. A. M., private communication and ref

(13) $\mathrm{Ir}\left[\mathrm{C}_{6} \mathrm{H}_{3}\left(\mathrm{CH}_{2} \mathrm{NMe}_{2}\right)_{2}-0,0^{\prime}\right](\mathrm{COD})$ was independently synthesized from $[\operatorname{IrCl}(\mathrm{COD})]_{2}$ and $\mathrm{Li}_{2}\left[\mathrm{C}_{6} \mathrm{H}_{3}\left(\mathrm{CH}_{2} \mathrm{NMe}_{2}\right)_{2}-0,0^{\prime}\right]_{2}$ in hexane; see ref 19 . 
Table I. Crystal Data and Details of the Structure Determination

\begin{tabular}{lc}
\hline & a. Crystal Data \\
formula & $\mathrm{C}_{20} \mathrm{H}_{31} \mathrm{~N}_{2} \mathrm{Rh}$ \\
mol wt & 402.38 \\
space group & $P \overline{1}$ \\
cryst system & triclinic \\
$a, \AA$ & $10.169(1)$ \\
$b, \AA$ & $13.036(1)$ \\
$c, \AA$ & $14.688(2)$ \\
$\alpha, \mathrm{deg}$ & $79.54(1)$ \\
$\beta, \mathrm{deg}$ & $77.04(1)$ \\
$\gamma, \mathrm{deg}$ & $79.53(1)$ \\
$V, \AA^{3}$ & $1845.6(4)$ \\
$Z$ & 4 \\
$D($ calcd), g cm & \\
$F(000)$, electrons & 1.448 \\
$\mu($ Mo K $\alpha), \mathrm{cm}^{-1}$ & 840 \\
approx cryst size, mm & 9.1 \\
\hline
\end{tabular}

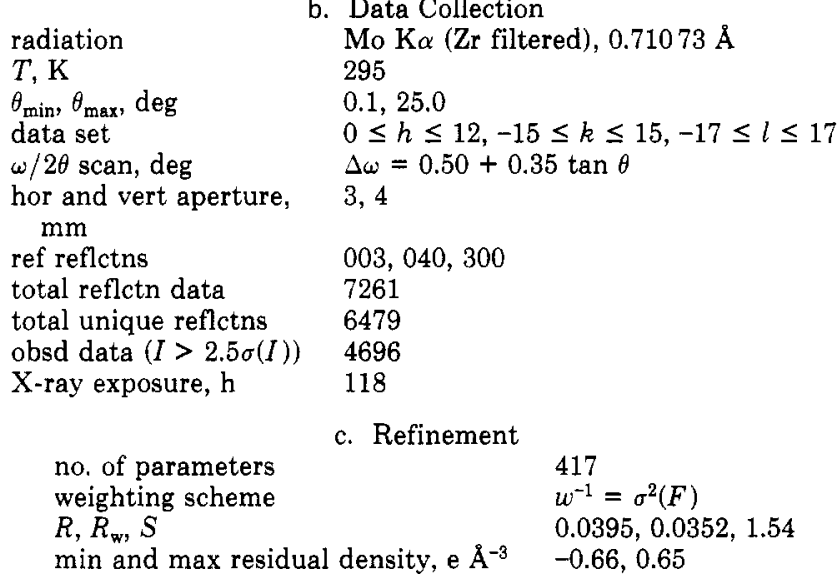

Unit cell parameters were derived by least squares from the diffractometer settings of 25 reflections $^{14 a}$ in the range $6.2<\theta$ $<12.2^{\circ}$. The three reference reflections showed a small decay of $2 \%$ over $118 \mathrm{~h}$ of $\mathrm{X}$-ray exposure time. The standard deviations in the intensities were adjusted according to an analysis of the variance of the reference reflections: ${ }^{14 \mathrm{~b}} \sigma^{2}(I)=\sigma_{\text {cs }}^{2}(I)+(0.02 I)^{2}$. Data were corrected for the small decay and $\mathrm{Lp}$ effects. Absorption correction was applied after convergence of the isotropic refinement $(R=0.08)$ according to the empirical correction method described by Walker and Stuart ${ }^{14 c}$ (range of corrections 0.869-1.112). The structure was solved by Patterson methods with the program SHELXS84 $4^{14 \mathrm{~d}}$ and refined on $F$ by blocked fullmatrix least squares. Hydrogen atoms were introduced at calculated positions ( $\mathrm{C}-\mathrm{H}=1.08 \AA$ ) with a fixed isotropic temperature factor $\left(U=0.1 \AA^{2}\right)$ for the methyl group hydrogen atoms and refined with fixed geometry with respect to their carrier atoms The refined parameter set included a scale factor, the coordinates of the nonhydrogen atoms, their anisotropic thermal parameters, and one overall isotropic temperature factor for the non-methyl group $\mathrm{H}$ atoms. Final positional parameters are listed in Table II. Scattering factors were taken from ref $14 \mathrm{e}, \mathrm{f}$ and corrected for anomalous dispersion. ${ }^{148}$ Most calculations were carried out on the CDC-CYBER-855 of the University of Utrecht with programs of the SHEL X76 package ${ }^{14 \mathrm{~h}}$ and EUCLID package ${ }^{14 \mathrm{i}}$ (calculation of geometrical data and preparation of illustrations).

(14) (a) de Boer, J. L.; Duisenberg, A. J. M. Acta Crystallogr., Sect. A: Found. Crystallogr. 1984, A40, C410. (b) McCandlish, L. E.; Stout, G. H.; Andrews, L. C. Acta Crystallogr., Sect. A: Cryst. Phys., Diffr., Theor. Gen. Crystallogr. 1975, A31, 245. (c) Walker, N.: Stuart, D. Acta Crystallogr., Sect. A: Found. Crystallogr. 1983, A39, 158. (d) Sheldrick, G. M. SHEL XS84, Program for Crystal Structure Determination, University of Goettingen, FRG, 1984. (e) Cromer, D. T.; Mann, J. B. Acta Crystallogr Sect. A. Cryst. Phys, Diffr. Theor. Gen Crystallogr 1968, A24, 321. (f) Cromer, D. T.; Liberman, D. J. Chem. Phys. 1970, 53, 1891. (g) Stewart, R. F.; Davidson, E. R.; Simpson, W. T. J. Chem. Phys. 1965, 42, 3175. (h) Sheldrick, G. M. SHELX76, Crystal Structure Analysis Package, University of Cambridge England 1976. (i) Spek, A. L In Computational Crystallography, Sayre, D., Ed.; Clarendon: Oxford, 1982; p 528.
Table II. Positional and Equivalent Isotropic Thermal Parameters of the Non-Hydrogen Atoms of $\mathrm{Rh}\left[\mathrm{C}_{6} \mathrm{H}_{3}\left(\mathrm{CH}_{2} \mathrm{NMe}_{2}\right)_{2}-0, o^{\prime}\right](\mathrm{COD})$

\begin{tabular}{|c|c|c|c|c|}
\hline atom & $x$ & $y$ & $z$ & $U_{\mathrm{eq}},{ }^{a} \AA^{2}$ \\
\hline \multicolumn{5}{|c|}{ Molecule 1} \\
\hline $\mathrm{Rh}(1)$ & $0.04010(4)$ & $0.21825(3)$ & $0.26110(3)$ & $0.0397(2)$ \\
\hline$N(1)$ & $0.4172(5)$ & $0.2357(4)$ & $0.4325(3)$ & $0.057(2)$ \\
\hline $\mathrm{N}(2)$ & $0.0617(4)$ & 0.2931 & $0.1144(3)$ & $0.042(2)$ \\
\hline $\mathrm{C}(1)$ & $0.2512(5)$ & $0.2278(4)$ & $0.2288(4)$ & $0.042(2)$ \\
\hline$C(2)$ & $0.2975(5)$ & $0.2323(3)$ & $0.1301(3)$ & $0.038(2)$ \\
\hline $\mathrm{C}(3)$ & $0.4316(6)$ & $0.2377(4)$ & $0.0859(4)$ & $0.047(2)$ \\
\hline $\mathrm{C}(4)$ & $0.5278(6)$ & 0.2382 & $0.1385(4)$ & $0.052(2)$ \\
\hline $\mathrm{C}(5)$ & $0.4856(6)$ & $0.2382(4)$ & $0.2348(4)$ & $0.053(2)$ \\
\hline $\mathrm{C}(6)$ & $0.3513(5)$ & 0.2348 & $0.2791(4)$ & $0.050(2)$ \\
\hline $\mathrm{C}(7)$ & $0.3107(6)$ & $0.2526(6)$ & $0.3845(4)$ & $0.085(3)$ \\
\hline $\mathrm{C}(8)$ & $0.4633(9)$ & $0.1240(5)$ & $0.4557(5)$ & $0.105(4)$ \\
\hline $\mathrm{C}(9)$ & $0.3829(8)$ & $0.2794(6)$ & $0.5192(5)$ & $0.089(3)$ \\
\hline$C(10)$ & $0.1944(6)$ & $0.2364(4)$ & $0.0707(4)$ & $0.047(2)$ \\
\hline$C(11)$ & $0.0738(7)$ & $0.4050(4)$ & $0.1102(4)$ & $0.061(3)$ \\
\hline $\mathrm{C}(12)$ & $-0.0405(6)$ & 0.2895 & $0.0584(4)$ & $0.066(3)$ \\
\hline $\mathrm{C}(13)$ & $0.0600(5)$ & $0.0906(4)$ & $0.3714(3)$ & $0.050(2)$ \\
\hline$C(14)$ & $-0.0003(5)$ & $0.1794(4)$ & $0.4118(3)$ & $0.048(2)$ \\
\hline $\mathrm{C}(15)$ & $-0.1492(6)$ & $0.2043(5)$ & $0.4577(4)$ & $0.059(3)$ \\
\hline$C(16)$ & $-0.2334(5)$ & $0.2738(4)$ & $0.3901(4)$ & 0.060 \\
\hline $\mathrm{C}(17)$ & $-0.1842(5)$ & $0.2526(5)$ & $0.2908(4)$ & $0.050(2)$ \\
\hline $\mathrm{C}(18)$ & $-0.1478(6)$ & $0.1536(5)$ & $0.2631(4)$ & $0.052(2)$ \\
\hline $\mathrm{C}(19)$ & $-0.1542(6)$ & $0.0505(4)$ & $0.3295(4)$ & $0.056(2)$ \\
\hline $\mathrm{C}(20)$ & $-0.0182(6)$ & $0.0066(4)$ & $0.3598(4)$ & $0.061(3)$ \\
\hline \multicolumn{5}{|c|}{ Molecule 2} \\
\hline $\operatorname{Rh}(1)$ & $0.56821(4)$ & $0.72182(3)$ & $0.20654(3)$ & $0.0376(2)$ \\
\hline $\mathrm{N}(1)$ & $0.9167(5)$ & $0.6237(4)$ & $0.3308(3)$ & $0.052(2)$ \\
\hline $\mathrm{N}(2)$ & $0.4785(4)$ & $0.8870(3)$ & $0.1883(3)$ & $0.045(2)$ \\
\hline $\mathrm{C}(1)$ & $0.7502(5)$ & 0.7902 & $0.1766(3)$ & 0.038 \\
\hline $\mathrm{C}(2)$ & $0.7225(5)$ & $0.8959(4)$ & 0.1329 & $0.043(2)$ \\
\hline $\mathrm{C}(3)$ & $0.8194(7)$ & $0.9641(4)$ & $0.1044(4)$ & $0.057(3)$ \\
\hline $\mathrm{C}(4)$ & $0.9501(7)$ & $0.9280(5)$ & 0.1165 & 0.064 \\
\hline $\mathrm{C}(5)$ & $0.9837(6)$ & $0.8259(5)$ & 0.1588 & $0.056(2)$ \\
\hline $\mathrm{C}(6)$ & $0.8860(5)$ & 0.7571 & 0.1882 & 0.044 \\
\hline$C(7)$ & $0.9425(5)$ & $0.6464(4)$ & $0.2290(4)$ & $0.045(2)$ \\
\hline $\mathrm{C}(8)$ & $0.9789(6)$ & $0.6912(5)$ & $0.3738(4)$ & 0.068 \\
\hline $\mathrm{C}(9)$ & $0.9722(7)$ & $0.5141(5)$ & $0.3595(5)$ & $0.077(3)$ \\
\hline $\mathrm{C}(10)$ & $0.5835(6)$ & $0.9364(4)$ & $0.1140(4)$ & $0.048(2)$ \\
\hline $\mathrm{C}(11)$ & $0.4699(6)$ & $0.9284(4)$ & $0.2768(4)$ & $0.063(3)$ \\
\hline $\mathrm{C}(12)$ & $0.3464(6)$ & $0.9188(4)$ & $0.1592(4)$ & $0.067(3)$ \\
\hline $\mathrm{C}(13)$ & $0.6661(5)$ & $0.5713(4)$ & $0.1733(4)$ & $0.044(2)$ \\
\hline $\mathrm{C}(14)$ & $0.6398(5)$ & $0.5679(4)$ & $0.2701(4)$ & $0.044(2)$ \\
\hline $\mathrm{C}(15)$ & $0.5286(6)$ & $0.5130(4)$ & $0.3379(4)$ & 0.062 \\
\hline $\mathrm{C}(16)$ & $0.3939(6)$ & $0.5870(4)$ & $0.3595(4)$ & $0.065(2)$ \\
\hline $\mathrm{C}(17)$ & $0.3713(6)$ & $0.6738(5)$ & $0.2795(4)$ & 0.054 \\
\hline $\mathrm{C}(18)$ & $0.3902(5)$ & $0.6601(4)$ & $0.1856(4)$ & $0.056(3)$ \\
\hline $\mathrm{C}(19)$ & $0.4304(6)$ & $0.5551(5)$ & $0.1503(5)$ & $0.069(3)$ \\
\hline $\mathrm{C}(20)$ & $0.5847(6)$ & $0.5277(4)$ & $0.1193(4)$ & 0.060 \\
\hline
\end{tabular}

${ }^{a} U_{\mathrm{eq}}=1 / 3 \sum_{i j} U_{i j} a_{i}{ }^{*} a_{j}^{*} \mathbf{a}_{i} \cdot \mathbf{a}_{j}$.

\section{Results and Discussion}

Synthesis of $\mathrm{Rh}\left[\mathrm{C}_{6} \mathrm{H}_{3}\left(\mathrm{CH}_{2} \mathrm{NMe}_{2}\right)-o-\mathrm{R}-o^{\prime}\right](\mathrm{COD})$ $\left[R=\mathrm{CH}_{2} \mathrm{NMe}_{2}(\mathrm{la}), \mathrm{Me}(2)\right.$, and $\left.\mathrm{H}(3)\right]$ and $\mathrm{Rh}$ $\left[\mathrm{C}_{6} \mathrm{H}_{3}\left(\mathrm{CH}_{2} \mathrm{NMe}_{2}\right)_{2}-\boldsymbol{o}, \boldsymbol{o}^{\prime}\right](\mathrm{NBD})(\mathbf{b})$. The reaction of equimolar amounts of $\mathrm{Li}_{2}\left[\mathrm{C}_{6} \mathrm{H}_{3}\left(\mathrm{CH}_{2} \mathrm{NMe}_{2}\right)_{2}-o, o^{\prime}\right]_{2}$ with $[\mathrm{RhCl} \text { (diene) }]_{2}$ in either diethyl ether, hexane, or benzene leads to the formation of $\mathrm{Rh}\left[\mathrm{C}_{6} \mathrm{H}_{3}\left(\mathrm{CH}_{2} \mathrm{NMe}_{2}\right)_{2}-0, o^{\prime}\right]$ (diene) [diene = COD (1a) or NBD (1b)], which can be isolated in good yield (eq 2). Due to the insolubility of their respective lithium precursors the solvent medium chosen for the syntheses of $\mathrm{Rh}\left[\mathrm{C}_{6} \mathrm{H}_{3}\left(\mathrm{CH}_{2} \mathrm{NMe}_{2}\right)-0-\mathrm{Me}-o^{\prime}\right](\mathrm{COD})(2)$ and $\mathrm{Rh}\left[\mathrm{C}_{6} \mathrm{H}_{4}\left(\mathrm{CH}_{2} \mathrm{NMe}_{2}\right)-o\right](\mathrm{COD})$ (3) was benzene in which $[\mathrm{RhCl}(\mathrm{COD})]_{2}$ is soluble (eq 2 ).

The new, orange compounds 1-3 are soluble in most organic solvents but react with water, alcohols, and a number of halogenated solvents (vide infra). Although they are very air-sensitive, they are thermally stable to at least $100^{\circ} \mathrm{C}$ both in solution and in the solid state.

The stability of 1-3 stands in sharp contrast with that of the products obtained by Muetterties et $a .^{15}$ and 


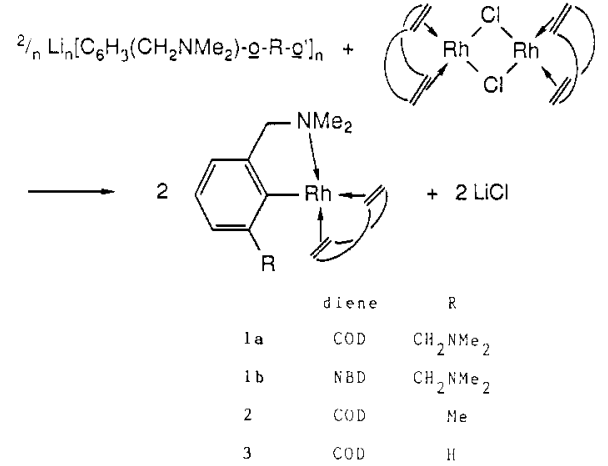

Mueller et al ${ }^{16}$ via reaction of $[\mathrm{MCl}(\mathrm{COD})]_{2}(\mathrm{M}=\mathrm{Rh}, \mathrm{Ir})$ with various organolithium and Grignard reagents. In the absence of additional ligands the initial compounds [MR(COD) $]_{2}$ obtained in this manner tend to be very reactive toward $\mathrm{C}-\mathrm{H}$ bonds and react further through a variety of intramolecular hydrogen-abstraction processes. The reactivity of these dimers clearly stems from the combination of an unsaturated metal center and the weak electrondeficient bridges of unsupported organo groups. In view of this general instability of $\mathrm{RhR}$ (diene) species, the striking thermal stability of 1-3 already points to the occurrence of intramolecular $\mathrm{Rh}-\mathrm{N}$ coordination in these new rhodium(I) complexes.

Similarly, in 1978 van Koten et al. reported the reaction of arylcuprates $\left(\mathrm{Cu}_{2} \mathrm{Li}_{2} \mathrm{R}_{4}\right)$ with $\left[\mathrm{RhCl}(\mathrm{CO})_{2}\right]_{2} \cdot{ }^{17}$ When the aryl group contained an ortho substituent capable of intramolecular coordination, as in $\left[\mathrm{C}_{6} \mathrm{H}_{4}\left(\mathrm{CH}_{2} \mathrm{NMe}_{2}\right)-o\right]$, a stable monomeric arylrhodium(I) complex could be obtained (eq 3 ). In contrast, the reaction of $\mathrm{Li}_{2} \mathrm{Cu}_{2} \mathrm{R}_{4}(\mathrm{R}=$
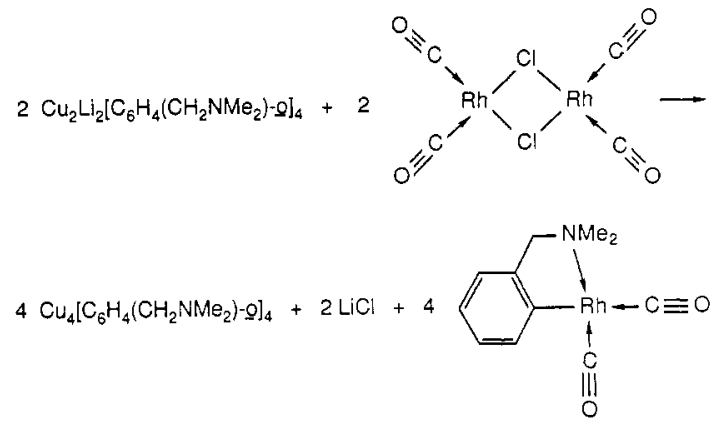

$o-\mathrm{MeC}_{6} \mathrm{H}_{4}-$ or $p-\mathrm{MeC}_{6} \mathrm{H}_{4}-$ ), where stabilizing ligands are absent, with $\left[\mathrm{RhCl}(\mathrm{CO})_{2}\right]_{2}$ leads to the formation of ketones, biphenyls, and metallic rhodium.

Solid-State Structure of $\mathrm{Rh}\left[\mathrm{C}_{6} \mathrm{H}_{3}\left(\mathrm{CH}_{2} \mathrm{NMe}_{2}\right)_{2}\right.$ $\left.o, o^{\prime}\right](\mathrm{COD})$ (1a). The crystal structure of $1 \mathrm{a}$ consists of four discrete molecules in a triclinic unit cell. The asymmetric unit comprises two crystallographically independent molecules (Figure 1). Selected bond distances, bond an-

(15) (a) Schmidt, G. F.; Muetterties, E. L.; Beno, M. A.; Williams, J. M. Proc. Natl. Acad. Sci. U.S.A. 1981, 78, 1318. (b) Kulzick, M.; Price, R. T.; Muetterties, E. L. Organometallics 1982, 1, 1256.

(16) (a) Mueller, J.; Holzinger, W.; Menig, H. Angew. Chem. 1976, 88 768. (b) Mueller, J.; Menig, H.; Rinze, P. V. J. Organomet. Chem. 1979, 181, 387. (c) Mueller, J.; Menig, H.; Huttner, G.; Frank, A. J. Organomet Chem. 1980, 185, 251. (d) Mueller, J. Menig, H. J. Organomet. Chem. 1980, 191, 303. (e) Mueller, J.; Haehnlein, W.; Menig, H.; Pickardt, J. J. Organomet. Chem. 1980, 197, 95. (f) Mueller, J.; Menig, H.; Pickardt, J. Angew. Chem. 1981, 93, 407. (g) Mueller, J.; Stock, R.; Pickardt, J. $Z$. Naturforsch., B: Anorg. Chem., Org. Chem. 1981, 36B, 1219. (h) Mueller, J.; Passon, B.; Pickardt, J. J. Organomet. Chem. 1982, 228, C51. (i) Mueller, J.; Haehnlein, W.; Passon, B. Z. Naturforsch., B: Anorg. Chem., Org. Chem. 1982, 37, 1573. (j) Mueller, J.; Haensch, C.; Pickardt, J. J. Organomet. Chem. 1983, 259, C21. (k) Mueller, J.; Passon, B. J. Organomet. Chem. 1983, 247, 131.

(17) van Koten, G.; Jastrzebski, J. T. B. H.; Noltes, J. G. J. Organomet. Chem. 1978, 148, 317. gles, and torsion angles for both molecules are listed in Tables III-V. The geometrical data of the two molecules, which have virtually identical coordination spheres around rhodium, are generally very similar, and therefore, unless these data differ by more than $2 \sigma$, only molecule 1 will be described. The rhodium atom has a square-planar coordination geometry. The aryl ligand coordinates as a bidentate ligand via the nitrogen atom of one amino group $[\mathrm{Rh}(1)-\mathrm{N}(2)=2.178(4) \AA]$ and the aryl carbon atom $[R h(1)-C(1)=2.114(5) \AA]$. Note that this is the first complex identified in which the $\left[\mathrm{C}_{6} \mathrm{H}_{3}\left(\mathrm{CH}_{2} \mathrm{NMe}_{2}\right)_{2}-0,0^{\prime}\right]$ ligand is not coordinated in a terdentate fashion. ${ }^{1}$

The two double bonds of COD, which exhibits a slightly twisted boat conformation, complete the coordination sphere of rhodium. The distances from the rhodium atom to the midpoint of the $\mathrm{C}(13)=\mathrm{C}(14)$ bond is 2.015 (4) $\AA$ $[\mathrm{m}(1)$, trans to $\mathrm{N}]$ and to the midpoint of $\mathrm{C}(17)=\mathrm{C}(18)$ bond is 2.098 (4) $\AA$ [m(2), trans to $\mathrm{C}(\operatorname{aryl})]$, though there is no significant difference in the lengths of the double bonds themselves $[\mathrm{C}(13)=\mathrm{C}(14)=1.377(7), \mathrm{C}(17)=\mathrm{C}(18)$ $=1.385(9) \AA]$. As found in other structures containing the $\mathrm{Rh}(\mathrm{COD})$ fragment ${ }^{18}$ local repulsions within the coordination sphere are such that there is no evident correlation between $\mathrm{C}=\mathrm{C}$ and $\mathrm{Rh}-\mathrm{C}$ (olefin) distances. The $\mathrm{m}(1)-\mathrm{Rh}(1)-\mathrm{m}(2)$ angle is $86.3(2)^{\circ}$.

The small $\mathrm{N}(2)-\mathrm{Rh}(1)-\mathrm{C}(1)$ angle of $79.9(2)^{\circ}\left[81.4(2)^{\circ}\right.$ in molecule 2] is due to the constraints of the five-membered chelate ring $\mathrm{Rh}(1)-\mathrm{C}(1)-\mathrm{C}(2)-\mathrm{C}(10)-\mathrm{N}(2)$. These ring constraints are in part responsible for the distortions of the bond angles around the aryl atom $\mathrm{C}(1)$ which is bound to the metal: $\mathrm{Rh}(1)-\mathrm{C}(1)-\mathrm{C}(2)=108.6(4)$, Rh(1) $-\mathrm{C}(1)-\mathrm{C}(6)=136.5(4)^{\circ}$, and $\mathrm{C}(2)-\mathrm{C}(1)-\mathrm{C}(6)=114.8$ $(5)^{\circ}$ (in a related square-planar iridium complex, Ir$\left[\mathrm{C}_{6} \mathrm{H}_{3}\left(\mathrm{CH}_{2} \mathrm{NMe}_{2}\right)_{2}-0, p\right](\mathrm{COD}),{ }^{19}$ and also in other $\left[\mathrm{C}_{6} \mathrm{H}_{4}-\right.$ $\left(\mathrm{CH}_{2} \mathrm{NMe}_{2}\right)_{-o}$ ] transition-metal complexes similar distortions are encountered). ${ }^{20}$ Despite these distortions the rhodium atom in 1 a does lie coplanar with the aryl ring. The aryl plane makes an angle of $28.1^{\circ}\left(18.3^{\circ}\right.$ in molecule 2 ) to the coordination plane defined by $\mathrm{N}(2), \mathrm{C}(1), \mathrm{m}(1)$, and $\mathrm{m}(2)$. In molecule $1 \mathrm{Rh}(1)$ shows a small displacement of 0.098 (8) $\AA$ out of the coordination plane, while in molecule $2 \mathrm{Rh}(2)$ lies exactly in this plane. A further, more pronounced, difference between molecules 1 and 2 is the conformation of the uncoordinated $\mathrm{CH}_{2} \mathrm{NMe}_{2}$ moiety (see Figure 1). This is best seen in the torsion angle C(5)-C(6) $-\mathrm{C}(7)-\mathrm{N}(1)$, which amounts to $-20.5(8)^{\circ}$ for molecule 1 and $100.0(5)^{\circ}$ for molecule 2 .

An important feature of the molecular structure of 1 a is that in both molecules, 1 and 2 , there exist some very short intramolecular nonbonding interactions between the aryl and COD ligands. They are most severe around the methylene part $[\mathrm{C}(7) \mathrm{H}(71) \mathrm{H}(72)]$ of the noncoordinated $\mathrm{CH}_{2} \mathrm{NMe}_{2}$ group and the neighboring double bond [H(3) $\mathrm{C}(13)=\mathrm{C}(14) \mathrm{H}(4)]: \mathrm{C}(7)-\mathrm{N}(4)=2.485(8), \mathrm{C}(14)-\mathrm{H}(71)$ $=2.532(8), \mathrm{H}(4)-\mathrm{H}(71)=1.784(8) \AA .^{21}$ There are also nonbonding interactions, although less severe, between the other double bond $[\mathrm{H}(73) \mathrm{C}(17)=\mathrm{C}(18) \mathrm{H}(84)]$ and one of the methyls $[\mathrm{C}(12) \mathrm{H}(21) \mathrm{H}(22) \mathrm{H}(23)]$ of the coordinated $\mathrm{CH}_{2} \mathrm{NMe}_{2}$ group: $\mathrm{H}(21)-\mathrm{H}(84)=2.019(8), \mathrm{H}(23)-\mathrm{H}(73)$

(18) (a) Brunner, H.; Beier, P.; Riepl, G.; Bernal, I.; Reisner, G. M.; Benn, R.; Rufinska, A. Organometallics 1985, 4, 1732. (b) Dick, D. G. Stephan, D. W. Can. J. Chem. 1986, 64, 1870. (c) Murray, B. D.; Hope, H.; Hvoslef, J.; Power, P. P. Organometallics 1984, 3, 657

(19) van der Zeijden, A. A. H.; van Koten, G.; Luijk, R.; Nordemann, R. A.; Spek, A. L. Organometallics 1988, 7, 1549.

(20) (a) Cotton, F. A. Mott, G. N. Organometallics 1982, 1, 38. (b) Manzer, L. E.; Gearhart, L. J.; Guggenberger, L. J.; Whitney, J. F. J. Chem. Soc., Chem. Commun. 1976, 942 . (c) van $\operatorname{der}$ Wal, W. F. J.; van der Wal, H. R. J. Organomet. Chem, 1978, 153, 335. 

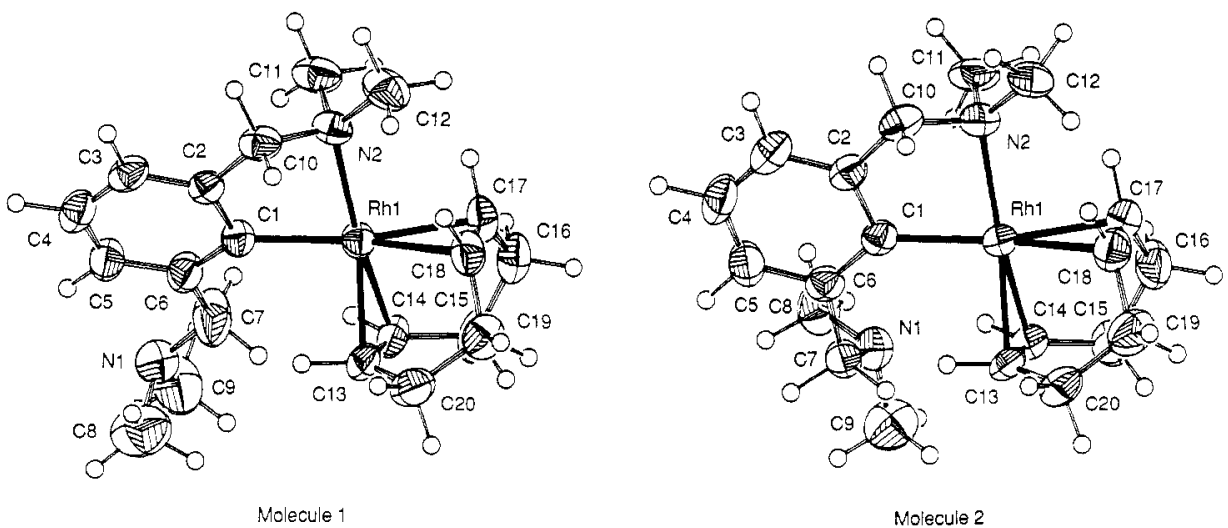

Figure 1. Molecular structure of $\mathrm{Rh}\left[\mathrm{C}_{6} \mathrm{H}_{3}\left(\mathrm{CH}_{2} \mathrm{NMe}_{2}\right)_{2}-0,0^{\prime}-C, N\right](\mathrm{COD})$ (1; molecules 1 and 2), with the adopted numbering scheme of the non-hydrogen atoms (thermal ellipsoid plot drawn at $50 \%$ probability level).

Table III. Selected Bond Distances $(\AA)$ of $\mathrm{Rh}\left[\mathrm{C}_{6} \mathrm{H}_{3}\left(\mathrm{CH}_{2} \mathrm{NMe}_{2}\right)_{2}-o, o^{\prime}\right](\mathrm{COD})^{a}$

\begin{tabular}{|c|c|c|c|c|c|}
\hline & \multicolumn{2}{|c|}{ molecule } & & \multicolumn{2}{|c|}{ molecule } \\
\hline & 1 & 2 & & 1 & 2 \\
\hline $\begin{array}{l}\mathrm{Rh}(1)-\mathrm{N}(2) \\
\mathrm{Rh}(1)-\mathrm{C}(1) \\
\mathrm{Rh}(1)-\mathrm{C}(13) \\
\mathrm{Rh}(1)-\mathrm{C}(14)\end{array}$ & $\begin{array}{l}2.178(4) \\
2.114(5) \\
2.117(5) \\
2.141(5)\end{array}$ & $\begin{array}{l}\text { (a) } A \\
2.174(4) \\
2.123(5) \\
2.121(5) \\
2.126(5)\end{array}$ & $\begin{array}{l}\text { Rhodium } \\
\text { Rh(1)-C(17) } \\
\text { Rh(1)-C(18) } \\
R h(1)-\mathrm{m}(1) \\
\mathrm{Rh}(1)-\mathrm{m}(2)\end{array}$ & $\begin{array}{l}2.202(5) \\
2.217(5) \\
2.015(4) \\
2.098(4)\end{array}$ & $\begin{array}{l}2.191(6) \\
2.211(5) \\
2.008(4) \\
2.087(4)\end{array}$ \\
\hline $\begin{array}{l}\langle\mathrm{N}(1)-\mathrm{C}\rangle \\
\langle\mathrm{N}(2)-\mathrm{C}\rangle\end{array}$ & $\begin{array}{l}1.42(3) \\
1.477(4)\end{array}$ & $\begin{array}{l}\text { (b) W } \\
1.46(1) \\
1.48(1)\end{array}$ & $\begin{array}{l}y l \text { Ligand } \\
C(2)-C(10) \\
C(6)-C(7) \\
\left\langle C\left(\mathrm{sp}^{2}\right)-C\left(\mathrm{sp}^{2}\right)\right\rangle\end{array}$ & $\begin{array}{l}1.495(8) \\
1.559(8) \\
1.39(1)\end{array}$ & $\begin{array}{l}1.485(8) \\
1.520(7) \\
1.40(2)\end{array}$ \\
\hline $\begin{array}{l}C(13)-C(14) \\
C(17)-C(18)\end{array}$ & $\begin{array}{l}1.377(7) \\
1.385(9)\end{array}$ & $\begin{array}{l}\text { (c) Wi } \\
1.381(8) \\
1.389(8)\end{array}$ & $\begin{array}{l}\text { D Ligand } \\
\left\langle\mathrm{C}\left(\mathrm{sp}^{2}\right)-\mathrm{C}\left(\mathrm{sp}^{3}\right)\right\rangle \\
\left\langle\mathrm{C}\left(\mathrm{sp}^{3}\right)-\mathrm{C}\left(\mathrm{sp}^{3}\right)\right\rangle\end{array}$ & $\begin{array}{l}1.51(1) \\
1.524(6)\end{array}$ & $\begin{array}{l}1.509(7) \\
1.529(6)\end{array}$ \\
\hline
\end{tabular}

a $\mathrm{m}(1)$ is the midpoint of $\mathrm{C}(13)-\mathrm{C}(14) ; \mathrm{m}(2)$ is the midpoint of $\mathrm{C}(17)-\mathrm{C}(18)$.

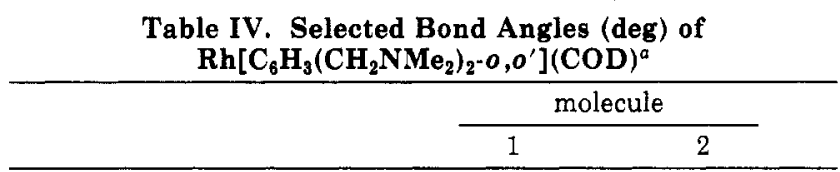

\begin{tabular}{lrr}
\multicolumn{3}{c}{ (a) Around Rhodium } \\
$\mathrm{N}(2)-\mathrm{Rh}(1)-\mathrm{C}(1)$ & $79.9(2)$ & $81.4(2)$ \\
$\mathrm{N}(2)-\mathrm{Rh}(1)-\mathrm{m}(1)$ & $174.0(2)$ & $179.2(5)$ \\
$\mathrm{N}(2)-\mathrm{Rh}(1)-\mathrm{m}(2)$ & $94.9(2)$ & $93.9(2)$ \\
$\mathrm{C}(1)-\mathrm{Rh}(1)-\mathrm{m}(1)$ & $98.4(2)$ & $98.1(2)$ \\
$\mathrm{C}(1)-\mathrm{Rh}(1)-\mathrm{m}(2)$ & $173.0(3)$ & $175.2(2)$ \\
$\mathrm{m}(1)-\mathrm{Rh}(1)-\mathrm{m}(2)$ & $86.3(2)$ & $86.6(2)$
\end{tabular}

(b) Within Aryl Ligand

$\begin{array}{lll}\langle\mathrm{C}-\mathrm{N}(1)-\mathrm{C}\rangle & 110(3) & 110(2) \\ \langle\mathrm{C}-\mathrm{N}(2)-\mathrm{C}\rangle & 108.4(9) & 108.3(2) \\ \operatorname{Rh}(1)-\mathrm{N}(2)-\mathrm{C}(10) & 101.8(3) & 102.8(3) \\ \mathrm{Rh}(1)-\mathrm{N}(2)-\mathrm{C}(11) & 108.5(3) & 108.0(3) \\ \operatorname{Rh}(1)-\mathrm{N}(2)-\mathrm{C}(12) & 120.8(3) & 120.5(3) \\ \operatorname{Rh}(1)-\mathrm{C}(1)-\mathrm{C}(2) & 108.6(4) & 108.5(4) \\ \operatorname{Rh}(1)-\mathrm{C}(1)-\mathrm{C}(6) & 136.5(4) & 136.6(4) \\ \mathrm{C}(2)-\mathrm{C}(1)-\mathrm{C}(6) & 114.8(5) & 114.9(5) \\ \mathrm{N}(1)-\mathrm{C}(7)-\mathrm{C}(6) & 115.6(5) & 115.5(4) \\ \mathrm{N}(2)-\mathrm{C}(10)-\mathrm{C}(2) & 109.6(4) & 110.8(4)\end{array}$

(c) Within COD Ligand

$\begin{array}{lll}\left\langle\mathrm{C}\left(\mathrm{sp}^{2}\right)-\mathrm{C}\left(\mathrm{sp}^{2}\right)-\mathrm{C}\left(\mathrm{sp}^{3}\right)\right\rangle & 125.1(9) & 124.8(4) \\ \left\langle\mathrm{C}\left(\mathrm{sp}^{2}\right)-\mathrm{C}\left(\mathrm{sp}^{3}\right)-\mathrm{C}\left(\mathrm{sp}^{3}\right)\right\rangle & 112.9(7) & 113.1(7)\end{array}$

${ }^{a} \mathrm{~m}(1)$ is the midpoint of $\mathrm{C}(13)-\mathrm{C}(14) ; \mathrm{m}(2)$ is the midpoint of $\mathrm{C}(17)-\mathrm{C}(18)$.

$=2.125(8) \AA^{21}$ These intramolecular repulsions, however, are only marginally responsible for the somewhat large $\mathrm{Rh}-\mathrm{C}(1)-\mathrm{C}(6)$ angle of $136.5(4)^{\circ}$, mentioned earlier.

(21) These distances are based on calculated positions of $\mathrm{H}$ atoms, assuming $\mathrm{sp}^{2}$ and $\mathrm{sp}^{3}$ hybridization of $\mathrm{C}$ atoms. The $\mathrm{H}$ atoms of the coordinated double bonds are in fact almost certainly bent away to some degree from the $\mathrm{Rh}$ center.
Table V. Selected Torsion Angles (deg) of

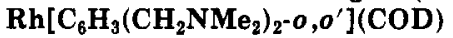

\begin{tabular}{lrr}
\hline & \multicolumn{2}{c}{ molecule } \\
\cline { 2 - 3 } & \multicolumn{1}{c}{1} & \multicolumn{1}{c}{2} \\
\hline $\mathrm{C}(1)-\mathrm{C}(6)-\mathrm{C}(7)-\mathrm{N}(1)$ & $166.6(5)$ & $-82.1(6)$ \\
$\mathrm{C}(5)-\mathrm{C}(6)-\mathrm{C}(7)-\mathrm{N}(1)$ & $-20.5(8)$ & $100.0(5)$ \\
$\mathrm{C}(8)-\mathrm{N}(1)-\mathrm{C}(7)-\mathrm{C}(6)$ & $-75.1(7)$ & $-61.8(6)$ \\
$\mathrm{C}(9)-\mathrm{N}(1)-\mathrm{C}(7)-\mathrm{C}(6)$ & $164.1(6)$ & $177.9(5)$ \\
$\mathrm{C}(1)-\mathrm{C}(2)-\mathrm{C}(10)-\mathrm{N}(2)$ & $31.7(6)$ & $33.0(6)$ \\
$\mathrm{C}(3)-\mathrm{C}(2)-\mathrm{C}(10)-\mathrm{N}(2)$ & $-145.5(4)$ & $-148.4(4)$ \\
$\mathrm{Rh}(1)-\mathrm{N}(2)-\mathrm{C}(10)-\mathrm{C}(2)$ & $-47.5(4)$ & $-43.8(4)$ \\
$\mathrm{C}(11)-\mathrm{N}(2)-\mathrm{C}(10)-\mathrm{C}(2)$ & $67.1(5)$ & $70.3(5)$ \\
$\mathrm{C}(12)-\mathrm{N}(2)-\mathrm{C}(10)-\mathrm{C}(2)$ & $-176.0(4)$ & $-172.4(4)$
\end{tabular}

Solution Behavior of 1-3. The behavior of the rhodium(I) complexes 1-3 in solution was studied by ${ }^{1} \mathrm{H}$ and ${ }^{13} \mathrm{C}$ NMR spectroscopy, and the data are collected in $\mathrm{Ta}$ bles VI and VII, respectively.

The Diene Ligand. ${ }^{1} \mathrm{H}$ and ${ }^{13} \mathrm{C}$ NMR spectra of 1-3 taken between -80 and $+105^{\circ} \mathrm{C}$ show separate resonances for each of the two olefinic units of the COD and NBD ligands, indicating the presence of two different trans groups or environments. This is in accord with the solid-state structure of 1a in which these trans groups are seen to be the aryl carbon and the coordinated amine substituent of the aryl ligand. In solution, the bidentate coordination of the diene moiety is demonstrated by the $\mathrm{Rh}-\mathrm{C}$ couplings found on both olefinic ${ }^{13} \mathrm{C}$ resonances.

In order to assign the two olefinic ${ }^{1} \mathrm{H}$ signals in the rhodium complexes, we undertook NOE experiments at room temperature. In the case of $\mathrm{Rh}\left[\mathrm{C}_{6} \mathrm{H}_{4}\left(\mathrm{CH}_{2} \mathrm{NMe}_{2}\right)\right.$ o](COD) (3) saturation of the olefinic signal at $4.17 \mathrm{ppm}$ $\left(\mathrm{CD}_{2} \mathrm{Cl}_{2}\right)$ caused an increase of the doublet resonance at ca. $6.85 \mathrm{ppm}$, assigned to the aromatic ortho' proton. Consequently, this olefinic unit must be adjacent to this 
Table VI. ${ }^{1} \mathrm{H}$ NMR Data of $1-3$ and Some Other (Aryl)Rh' ${ }^{1}$ (diene) Complexes ${ }^{a}$

\begin{tabular}{|c|c|c|c|c|c|c|}
\hline compound & solv & $T\left({ }^{\circ} \mathrm{C}\right)$ & aryl & $\mathrm{CH}_{2}^{b}$ & $\mathrm{NMe}$ & $=\mathrm{CH}(\text { diene })^{c}$ \\
\hline \multirow[t]{2}{*}{ 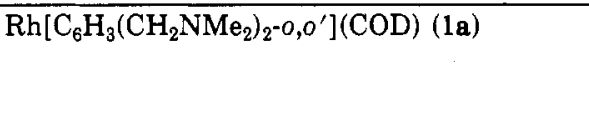 } & $\mathrm{CD}_{2} \mathrm{Cl}_{2}$ & +25 & $6.82(\mathrm{~m})$ & 3.52 & 2.28 & $\begin{array}{l}4.09 \\
4.89\end{array}$ \\
\hline & $\mathrm{C}_{6} \mathrm{D}_{5} \mathrm{CD}_{3}$ & +25 & $7.29(\mathrm{~m})$ & 3.72 & 2.30 & $\begin{array}{l}4.04 \\
5.54\end{array}$ \\
\hline \multirow[t]{3}{*}{$\mathrm{Rh}\left[\mathrm{C}_{6} \mathrm{H}_{3}\left(\mathrm{CH}_{2} \mathrm{NMe}_{2}\right)_{2^{-}-, 0^{\prime}}\right](\mathrm{NBD})(\mathrm{lb})$} & $\mathrm{CD}_{2} \mathrm{Cl}_{2}$ & +25 & $6.78(\mathrm{~m})$ & 3.30 & 2.25 & $\begin{array}{l}4.05^{d} \\
4.59\end{array}$ \\
\hline & $\mathrm{C}_{6} \mathrm{D}_{5} \mathrm{CD}_{3}$ & +25 & $f$ & 3.50 & 2.26 & $\begin{array}{l}3.98^{e} \\
5.12\end{array}$ \\
\hline & $\mathrm{C}_{6} \mathrm{D}_{5} \mathrm{CD}_{3}$ & -80 & $f$ & $\begin{array}{l}3.47(\mathrm{br}) \\
3.73(\mathrm{br})\end{array}$ & $\begin{array}{l}1.91(\mathrm{br}) \\
2.53(\mathrm{br})\end{array}$ & $\begin{array}{l}4.02 \\
5.22\end{array}$ \\
\hline $\mathrm{Rh}\left[\mathrm{C}_{6} \mathrm{H}_{3}\left(\mathrm{CH}_{2} \mathrm{NMe}_{2}\right)-0-\mathrm{Me}-o^{\prime}\right](\mathrm{COD})(2)^{g}$ & $\mathrm{CD}_{2} \mathrm{Cl}_{2}$ & +25 & $6.95(\mathrm{~m})$ & 3.93 & 2.19 & $\begin{array}{l}4.12 \\
4.78\end{array}$ \\
\hline $\mathrm{Rh}\left[\mathrm{C}_{6} \mathrm{H}_{4}\left(\mathrm{CH}_{2} \mathrm{NMe}_{2}\right)-0\right](\mathrm{COD})(3)$ & $\mathrm{CD}_{2} \mathrm{Cl}_{2}$ & +25 & $6.83(\mathrm{~m})$ & 3.80 & 2.53 & $\begin{array}{l}3.89 \\
4.17\end{array}$ \\
\hline $\mathrm{Rh}\left[\mathrm{C}_{6} \mathrm{H}_{3}\left(\mathrm{CH}_{2} \mathrm{NMe}_{2}\right)_{2-0,0^{\prime}}\right](\mathrm{COD})(\mathrm{CO})$ & $\mathrm{C}_{6} \mathrm{D}_{5} \mathrm{CD}_{3}$ & -30 & $f$ & $\begin{array}{l}3.61(\mathrm{~d}) \\
4.24(\mathrm{~d})\end{array}$ & 2.28 & $\begin{array}{l}3.36 \\
4.87\end{array}$ \\
\hline $\mathrm{Rh}\left[\mathrm{C}_{6} \mathrm{H}_{3}\left(\mathrm{CH}_{2} \mathrm{NMe}_{2}\right)_{2}-o, 0^{\prime}\right](\mathrm{COD})\left(\mathrm{PPh}_{3}\right)^{h}$ & $\mathrm{C}_{6} \mathrm{D}_{5} \mathrm{CD}_{3}$ & -60 & $f$ & $4.08(\mathrm{~d})$ & 2.49 & $\begin{array}{l}4.24 \\
4.65\end{array}$ \\
\hline $\mathrm{Rh}\left[\mathrm{C}_{6} \mathrm{H}_{3}\left(\mathrm{CH}_{2} \mathrm{NMe}_{2}\right)_{2^{-0}, 0^{\prime}}\right](\mathrm{COD})(\mathrm{PhC} \equiv \mathrm{CPh})$ & $\mathrm{C}_{6} \mathrm{D}_{5} \mathrm{CD}_{3}$ & +10 & $f$ & $\begin{array}{l}3.21(\mathrm{~d}) \\
4.31(\mathrm{~d})\end{array}$ & 2.29 & $\begin{array}{l}3.72 \\
4.16\end{array}$ \\
\hline
\end{tabular}

${ }^{a}$ Measured at $250 \mathrm{MHz}$; chemical shifts in ppm relative to external TMS. ${ }^{b}$ For $\mathrm{AB}$ doublet: ${ }^{1} J=14 \mathrm{~Hz} .{ }^{c} \mathrm{Broad}$ resonances. ${ }^{d} \mathrm{CH}$ (NBD), $3.81 \mathrm{ppm} ; \mathrm{CH}_{2}$ (NBD), $1.4 \mathrm{ppm}$. ${ }^{e} \mathrm{CH}$ (NBD), $3.98 \mathrm{ppm} ; \mathrm{CH}_{2}$ (NBD), $1.54(\mathrm{~m}), 1.70(\mathrm{~m}) \mathrm{ppm}$. ${ }^{f}$ Obscured by solvent resonances. ${ }^{8} \mathrm{Me}(\operatorname{aryl}), 2.44 \mathrm{ppm}$. ${ }^{31} \mathrm{P} \mathrm{NMR} 23.5 \mathrm{ppm}\left({ }^{1} J_{\mathrm{Rh}}=166 \mathrm{~Hz}\right)$.

Table VII. ${ }^{13} \mathrm{C}$ NMR Data of the (Aryl) $\mathrm{Rh}^{\mathrm{I}}$ (diene) Complexes $1-3^{a}$

\begin{tabular}{|c|c|c|c|c|c|c|c|}
\hline \multirow[b]{2}{*}{ compound } & \multicolumn{6}{|c|}{ aryl ligand } & \multirow[b]{2}{*}{$=\mathrm{CH}$ (diene) } \\
\hline & $\mathrm{C}(1)$ & $\mathrm{C}(2,6)$ & $\mathrm{C}(3,5)$ & $\mathrm{C}(4)$ & $\mathrm{CH}_{2}$ & $\mathrm{NMe}$ & \\
\hline $\mathrm{Rh}\left[\mathrm{C}_{6} \mathrm{H}_{3}\left(\mathrm{CH}_{2} \mathrm{NMe}_{2}\right)_{\left.2^{-0}, o^{\prime}\right](\mathrm{COD})(1 \mathrm{a})}\right.$ & $165.5(41)$ & 148.3 & 123.6 & 124.7 & 69.4 & 47.5 & $\begin{array}{l}71.1(13)^{b} \\
87.9(8)\end{array}$ \\
\hline 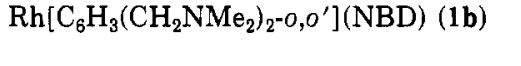 & $165.5(46)$ & 146.6 & 123.1 & $f$ & $68: 8$ & 47.4 & $\begin{array}{l}57.2(12)^{c} \\
72.0(6)\end{array}$ \\
\hline $\mathrm{Rh}\left[\mathrm{C}_{6} \mathrm{H}_{3}\left(\mathrm{CH}_{2} \mathrm{NMe}_{2}\right)-0-\mathrm{Me}-\mathrm{O}^{\prime}\right](\mathrm{COD})(2)$ & $f$ & $\begin{array}{l}148.9 \\
146.9\end{array}$ & $\begin{array}{l}127.8 \\
124.1\end{array}$ & 119.8 & 73.6 & 49.2 & $\begin{array}{l}70.8(14)^{d} \\
88.3(8)\end{array}$ \\
\hline $\mathrm{Rh}\left[\mathrm{C}_{6} \mathrm{H}_{4}\left(\mathrm{CH}_{2} \mathrm{NMe}_{2}\right)-o\right](\mathrm{COD})$ & $164.6(38)$ & $\begin{array}{l}149.8 \\
133.3\end{array}$ & $\begin{array}{l}124.7 \\
123.9\end{array}$ & 121.8 & 73.7 & 49.6 & $\begin{array}{l}71.8(15)^{e} \\
91.1(7)^{2}\end{array}$ \\
\hline
\end{tabular}

${ }^{a}$ Measured in $\mathrm{CD}_{2} \mathrm{Cl}_{2}$ at $62.89 \mathrm{MHz}$; chemical shifts in ppm relative to external TMS; ${ }^{1} J(\mathrm{Rh}-\mathrm{C})$ in $\mathrm{Hz}$ between parentheses. ${ }^{b} \mathrm{CH} \mathrm{H}_{2}(\mathrm{COD})$, 29.5, $32.7 \mathrm{ppm} .{ }^{c} \mathrm{CH}$ (NBD), 52.4 (2) ppm; $\mathrm{CH}_{2}$ (NBD), $64.3 \mathrm{ppm} .{ }^{d} \mathrm{CH}_{2}$ (COD), 29.3, $32.7 \mathrm{ppm} .{ }^{e} \mathrm{CH}_{2}$ (COD), 29.9, 31.6 ppm. ${ }^{f} \mathrm{Not}$ observed.

proton and hence is trans-N-positioned. Saturation of the other olefinic signal at $3.89 \mathrm{ppm}$ causes a small increase of the $\mathrm{NMe}_{2}$ resonance at $2.53 \mathrm{ppm}$, confirming that this olefinic unit must be trans-C-positioned. In the case of the other rhodium complexes 1 and 2, similar NOE experiments gave no definitive results, presumably due to fluxional behavior (vide infra), and no direct assignments of the olefinic signals could be made. However, on the basis of the results of complex 3 and by comparison of shift data with that of similar compounds, ${ }^{18,22}$ the more upfield resonance at $3.9-4.1 \mathrm{ppm}$ is tentatively assigned to the trans-C olefinic unit. In conjunction, the ${ }^{13} \mathrm{C}$ resonance at ca. $71 \mathrm{ppm}$ of $1 \mathrm{a}, 2$, and 3 ( $57 \mathrm{ppm}$ for $1 \mathrm{~b}$; see Table VII) is assigned to the trans-C olefin.

The Aryl Ligand and Its Fluxionality in 1. At -80 ${ }^{\circ} \mathrm{C}$ (in toluene- $d_{8}$ or $\mathrm{CD}_{2} \mathrm{Cl}_{2}$ at $250 \mathrm{MHz}$ ) the ${ }^{1} \mathrm{H} \mathrm{NMR}$ spectrum of the aryl ligand in $\mathbf{1 b}$ shows two sets of singlet $\mathrm{CH}_{2}$ and $\mathrm{NMe}_{2}$ resonances. This indicates the presence of one coordinated and one uncoordinated $\mathrm{CH}_{2} \mathrm{NMe}_{2}$ group, in accord with the solid-state structure of 1a. However, on warming to $-65^{\circ} \mathrm{C}$ the two sets of $\mathrm{CH}_{2} \mathrm{NMe}_{2}$ signals coalesce (independent of solvent and concentration) to only a single $\mathrm{NMe}_{2}$ and $\mathrm{CH}_{2}$ resonance pattern, which sharpens at higher temperatures. Similar behavior was also

(22) (a) Jans, R. J. F.; van Koten, G.; Vrieze, K.; Spek, A. L. Inorg. Chim. Acta 1987, 126, 49. (b) Crabtree, R. H.; Morris, G. E. J. Organomet. Chem. 1977, 135, 395. (c) Crabtree, R. H.; Gautier, A.; Giordano, G.; Khan, T. J. Organomet. Chem. 1977, 141, 113. (d) Platzer, N.: Goasdoue, N.; Bonnaire, R. J. Organomet. Chem. 1978, 160, 455. (e) Brodzki, D.; Pannetier, G. J. Organomet. Chem. 1976, 104, 241.

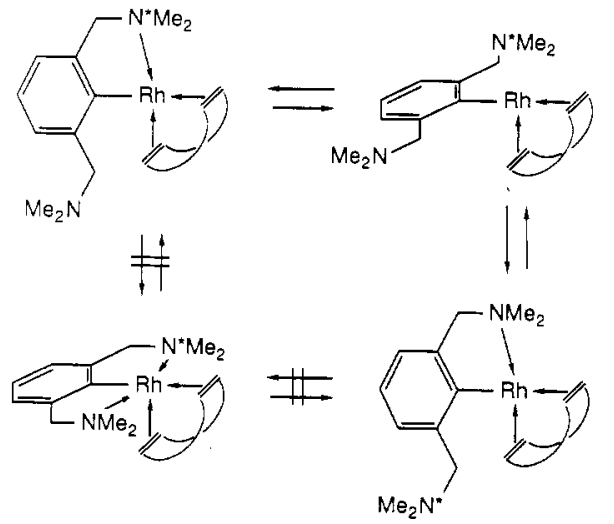

Figure 2. Possible mechanisms for the dynamic process of 1 .

observed for la, which had a coalescence temperature of ca. $-90{ }^{\circ} \mathrm{C}$ (in toluene- $d_{8}$ or $\mathrm{CD}_{2} \mathrm{Cl}_{2}$ ). Obviously, the $\mathrm{CH}_{2} \mathrm{NMe}_{2}$ groups of this ligand are involved in an intramolecular exchange process. At this point it is important to stress that at these higher temperatures one still observes two separate olefinic signals for the diene and their chemical shifts seem fairly insensitive to the exchange process occurring. With this constraint one can postulate two possible mechanisms for the dynamic processes in 1 , which both involve rotation of the aryl ligand about $\mathrm{Rh}-\mathrm{C}$ (Figure 2). The first is an associative mechanism with a five-coordinate square-pyramidal intermediate, and the second is a dissociative mechanism having a three-coordinate T-shaped intermediate. The former is regarded as 
unlikely since, first, in a five-coordinate intermediate there would be severe steric repulsions between the $\mathrm{CH}_{2} \mathrm{NMe}_{2}$ groups and the diene moiety (as already found in the four-coordinate situation, vide supra), and second, with rhodium(I) the tendency for five-coordination is low, especially if poorly ligating, hard nitrogen atoms are involved. Furthermore, the easy substitution of the coordinated $\mathrm{CH}_{2} \mathrm{NMe}_{2}$ group in 1a by a range of monodentate ligands (vide infra) suggests the occurrence of a dissociative mechanism.

Fluxionality in 2 and 3 ? The fluxional process exhibited by the arylrhodium(I) complexes 1 is probably due to intramolecular steric crowding, as reflected in the short nonbonding interactions found between the aryl and COD moieties in the X-ray structure of 1a. This steric crowding, which is most severe between the methylene part of the uncoordinated $\mathrm{CH}_{2} \mathrm{NMe}_{2}$ group and the adjacent COD double bond, can clearly be relieved by dissociation of the coordinated $\mathrm{CH}_{2} \mathrm{NMe}_{2}$ group and consecutive rotation of the aryl moiety about Rh-C(aryl). Consequently, if the uncoordinated $0^{\prime}-\mathrm{CH}_{2} \mathrm{NMe}_{2}$ group is substituted by a methyl group (as in 2), the fluxional process should not be greatly affected, since the steric crowding afforded by this methyl group will be similar. On the other hand, if this group is substituted by a much less sterically demanding hydrogen atom (as in 3), fluxional behavior should be less marked. Verification of these proposals is hampered by the fact that the NMR data of 2 and 3 (unlike those of 1) do not straightforwardly reflect the presence or absence of fluxionality. Therefore, to draw meaningful conclusions, (a) NOE experiments and (b) a careful comparison of ${ }^{1} \mathrm{H}$ and ${ }^{13} \mathrm{C}$ NMR shift values of the COD olefinic atoms were necessary.

(a) The aforementioned NOE experiments on 3 at room temperature indicate a steady interaction of the trans- $N$ olefinic protons with the adjacent ortho'-positioned aromatic $\mathrm{H}$ atom, and hence it can be concluded that complex 3 is not fluxional. The fact that NOE experiments on 1 did not reveal a similar interaction (with the methylene protons of the uncoordinated $o^{\prime}-\mathrm{CH}_{2} \mathrm{NMe}_{2}$ group) is consistent with the fluxionality shown by this complex. The fact that similar NOE experiments on 2 were also unsuccessful strongly suggests that complex 2 is also fluxional.

(b) It is known that the NMR chemical shifts of olefinic protons and carbons of a coordinated olefin are sensitive to the trans-positioned ligand, but more importantly, as reported by Crabtree and Morris, ${ }^{22 b}$ they correlate very reliably with the electronic effects of the trans ligand. From Tables VI and VII it can be seen that both the ${ }^{1} \mathrm{H}$ and ${ }^{13} \mathrm{C}$ chemical shifts of the trans- $\mathrm{N}$-positioned double bonds of 2 more resemble those of 1a than of 3, and clearly, these double bonds experience the same trans influence. Since it has been deduced that the aryl moiety of $1 \mathrm{a}$ is rotating about $\mathrm{Rh}-\mathrm{C}$ (aryl), the NMR data for 2 strongly point to the occurrence of the same process in this complex.

For all complexes a close similarity can be seen between the ${ }^{1} \mathrm{H}$ and ${ }^{13} \mathrm{C}$ NMR data of the trans- $\mathrm{C}$ double bonds. This is not unexpected, since these double bonds always experience the influence of $\mathrm{C}(\operatorname{aryl})$, whether there is rotation about $\mathrm{Rh}-\mathrm{C}(\operatorname{aryl})$ or not.

(Non)fluxionality in $1-3$ and Its Consequences. Apparently, chelate binding of the aryl ligand in $\mathbf{1}$ and 2 is not very effective. Nevertheless, despite the intermediacy of a highly unsaturated, three-coordinate, 14-electron species during the dynamic process, these complexes are thermally stable to at least $100^{\circ} \mathrm{C}$. This can in part be ascribed to the "ortho effect"; i.e., the alkyl groups of the aryl ligand shield the positions perpendicular to the co- ordination plane from chemical attack.

From the present findings, it has been concluded that this 14-electron T-shaped species must have a substantial barrier to rearrangement via $\mathrm{Y}$-shaped intermediates. This is supported by calculations on $\mathrm{ML}_{3} \mathrm{~d}^{8}$ metal complexes, for which it was found that the latter conformations were thermodynamically very unstable with respect to the $T$ shaped conformation. ${ }^{23}$ It is further noted that $\mathrm{T}$-shaped species are believed to be key intermediates in substitution reactions and in reactions of electrophiles or $\mathrm{C}-\mathrm{H}$ bonds in $\mathrm{d}^{8}$ metal complexes. ${ }^{24}$

Despite a possible protection by the "ortho effect" it is anticipated that the intermediacy of a 14-electron species in 1 and 2 will, compared to 3 , certainly enhance their reactivities. Although the 16-electron square-planar arrangement by itself already represents a reactive template, incoming reactants could be assisted by the presence of an extra vacant coordination site and an enhanced polarity of the $\mathrm{Rh}-\mathrm{C}$ bond in the 14 electron configuration of 1 .

(a) Reaction of 1a, 2, and 3 with Methanol. The difference in stability and reactivity of $1 \mathbf{a}$ and 2 compared to 3 is well-demonstrated by the reactions of these complexes with excess methanol (eq 4). By monitoring with $\mathrm{Rh}\left[\mathrm{C}_{6} \mathrm{H}_{3}\left(\mathrm{CH}_{2} \mathrm{NMe}_{2}\right)-o-\mathrm{R}-o^{\prime}\right](\mathrm{COD})+\mathrm{MeOH} \rightarrow$ $m-(\mathrm{R})\left(\mathrm{Me}_{2} \mathrm{NCH}_{2}\right) \mathrm{C}_{6} \mathrm{H}_{4}+1 / 2[\mathrm{Rh}(\mathrm{OMe})(\mathrm{COD})]_{2}$

${ }^{1} \mathrm{H}$ NMR, it was found that the reaction of the sterically less crowded $\mathrm{Rh}_{[}\left[\mathrm{C}_{6} \mathrm{H}_{4}\left(\mathrm{CH}_{2} \mathrm{NMe}_{2}\right)-0\right](\mathrm{COD})$ (3) with methanol takes about 3 days for completion whereas 1 and 2 react instantaneously.

(b) Reaction of $1 \mathrm{a}$ with Neutral Ligands. Complex la easily reacts with some monodentate ligands. Although no reaction was observed with amines (diethylamine, triethylamine, or pyridine) or olefins (cyclooctene, 1,5cyclooctadiene, or cis-stilbene), ${ }^{25}$ la reacts with the strong $\pi$-acceptor ligands $\mathrm{CO}$, diphenylethyne, and $\mathrm{PPh}_{3}$. However, at room temperature the resulting complexes proved too reactive to enable their isolation from the reaction mixtures. Therefore, these reactions, using various $\mathrm{L} / \mathrm{Rh}$ ratios, were started at $-80^{\circ} \mathrm{C}$ and monitored by NMR on raising the temperature. At different temperatures for each reagent a complex of apparent composition $\mathrm{Rh}$ $\left[\mathrm{C}_{6} \mathrm{H}_{3}\left(\mathrm{CH}_{2} \mathrm{NMe}_{2}\right)_{2}-0,0^{\prime}\right](\mathrm{COD})(\mathrm{L})^{26}$ was formed (see Table VI), but which disappeared at or above room temperature. The ${ }^{1} \mathrm{H}$ NMR spectra of these complexes, below their decomposition temperatures, still show the presence of two different olefinic groups for the coordinated COD. The four $\mathrm{CH}_{2}$ protons of the aryl moiety have become diastereotopic, as evidenced by $\mathrm{AB}$ doublets, but the $12 \mathrm{Me}$ protons appear to be equivalent, indicating that both $\mathrm{CH}_{2} \mathrm{NMe}_{2}$ groups are no longer coordinated. This points to the presence of a monodentate $\mathrm{C}$-bonded $\left[\mathrm{C}_{6} \mathrm{H}_{3}\right.$ $\left.\left(\mathrm{CH}_{2} \mathrm{NMe}_{2}\right)_{2}-0,0^{\prime}\right]$ ligand in which the formerly coordinated amino group has now been substituted by the incoming ligand $\mathrm{L}$ (eq 5). These reactions clearly corroborate the

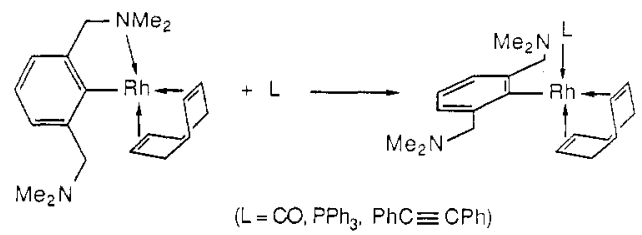

\footnotetext{
(23) Dedieu, A.; Hyla-Kryspin, I. J. Organomet. Chem. 1981, 115. (24) Crabtree, R. H. Chem. Rev. 1985, 85, 245.

(25) Dimethyl maleate, however, is catalytically isomerized by 1 to dimethyl fumarate.

(26) The ${ }^{31} \mathrm{P}$ NMR spectrum of $\mathrm{Rh}\left[\mathrm{C}_{6} \mathrm{H}_{3}\left(\mathrm{CH}_{2} \mathrm{NMe}_{2}\right)_{2}-0,0^{\prime}\right](\mathrm{COD})$ $\left(\mathrm{PPh}_{3}\right)$ in $\mathrm{C}_{6} \mathrm{D}_{5} \mathrm{CD}_{3}$ at $-60^{\circ} \mathrm{C}$ shows one doublet at $23.5 \mathrm{ppm}$ with $J_{\mathrm{Rh}}=$ $166 \mathrm{~Hz}$.
} 


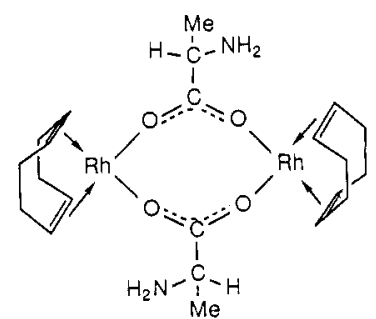

Figure 3. Proposed structure of $\left[\mathrm{Rh}(\mathrm{L} \text {-alanyl)(COD) }]_{2}\right.$.

mechanism of the fluxional process of 1 involving ready $\mathrm{Rh}-\mathrm{N}$ dissociation and intermediacy of a monodentate $\mathrm{C}$-bonded aryl ligand. Since the $\mathrm{CH}_{2}$ groups of the aryl ligand in $\mathrm{Rh}\left[\mathrm{C}_{6} \mathrm{H}_{3}\left(\mathrm{CH}_{2} \mathrm{NMe}_{2}\right)_{2}-0,0^{\prime}\right](\mathrm{COD})(\mathrm{L})$ are diastereotopic, it is further concluded that the aryl plane is now fixed in a position perpendicular to the coordination plane and is consequently not freely rotating around $\mathrm{Rh}-\mathrm{C}$ (aryl).

Reactivity of $\mathbf{R h}\left[\mathrm{C}_{6} \mathrm{H}_{3}\left(\mathrm{CH}_{2} \mathrm{NMe}_{2}\right)_{2}-0, o^{\prime}\right]$ (diene) (1). Protolysis Reactions. Although solid 1 decomposed rapidly in humid air, it was found that solutions of 1 in apolar solvents (benzene, alkanes) were relatively stable to added deoxygenated water. However, in polar solvents, like acetone and pyridine, a clean reaction of 1 with water occurs and $[\mathrm{RhOH} \text { (diene) }]_{2}$ and $m-\left(\mathrm{Me}_{2} \mathrm{NCH}_{2}\right)_{2} \mathrm{C}_{6} \mathrm{H}_{4}$ can be isolated quantitatively. This was found to be an example of a general type of reaction in which the rhodiumcarbon bond in 1 is broken by a more or less acidic hydrogen. This reaction occurs with a variety of protic reagents such as $\mathrm{HCl}, \mathrm{HBr}$, acetic acid, acetylacetone, water, L-alanine, and methanol, though not with the sterically demanding triphenylmethanol or with secondary amines. These protolysis reactions with $\mathrm{HX}$, summarized in eq $6 \mathrm{a}$, afford $m$-( $\left.\mathrm{Me}_{2} \mathrm{NCH}_{2}\right)_{2} \mathrm{C}_{6} \mathrm{H}_{4}$ and $[\mathrm{RhX} \text { (diene) }]_{n}$ ( $n=2$, except for $\mathrm{X}=$ acetylacetonate, where $n=1$ ).

$\mathrm{Rh}\left[\mathrm{C}_{6} \mathrm{H}_{3}\left(\mathrm{CH}_{2} \mathrm{NMe}_{2}\right)_{2}-o, o^{\prime}\right]$ (diene) $+\mathrm{HX} \rightarrow$

$$
1 / n[\mathrm{RhX} \text { (diene) }]_{n}+m-\left(\mathrm{Me}_{2} \mathrm{NCH}_{2}\right)_{2} \mathrm{C}_{6} \mathrm{H}_{4} \text { (6a) }
$$

$\mathrm{X}=$ acac, $n=1 ; \mathrm{X}=$

$$
\mathrm{Cl}, \mathrm{Br}, \mathrm{OAc}, \mathrm{OH}, \mathrm{OMe}, \mathrm{L}-\text { alanyl, } n=2
$$

$m-\left(\mathrm{Me}_{2} \mathrm{NCH}_{2}\right)_{2} \mathrm{C}_{6} \mathrm{H}_{4}+2 \mathrm{HX} \rightarrow$

$$
\left[m-\left(\mathrm{Me}_{2}(\mathrm{H}) \mathrm{NCH}_{2}\right)_{2} \mathrm{C}_{6} \mathrm{H}_{4}\right] \mathrm{X}_{2}
$$

$$
\mathrm{X}=\mathrm{Cl}, \mathrm{Br}, \mathrm{OAc}
$$

One example of the synthetic use of this reaction is the isolation of the new olefinic complex [Rh(L-alanyl)(COD) $]_{2}$, which has promising potential in the light of stereospecific catalysis. This complex, shown schematically in Figure 3 , has been identified as a carboxylate-bridged dimer by FD mass and NMR spectroscopy.

In those cases where the $\mathrm{HX}$ reagent was strongly acidic, the base $m$ - $\left(\mathrm{Me}_{2} \mathrm{NCH}_{2}\right)_{2} \mathrm{C}_{6} \mathrm{H}_{4}$ was isolated as its bis (ammonium) salt $\left[m-\left(\mathrm{Me}_{2}(\mathrm{H}) \mathrm{NCH}_{2}\right)_{2} \mathrm{C}_{6} \mathrm{H}_{4}\right] \mathrm{X}_{2}(\mathrm{X}=\mathrm{Cl}, \mathrm{Br}$, OAc; eq 6b). Since complex 1 has one or maybe two free amino groups, their protonation could take place either before or after protonolysis of the $\mathrm{Rh}-\mathrm{C}$ bond. When the addition of acetic acid to $1 \mathrm{a}$ in $\mathrm{CD}_{2} \mathrm{Cl}_{2}$ was followed by ${ }^{1} \mathrm{H}$ NMR, it was found that the first equivalent of acid solely broke the $\mathrm{Rh}-\mathrm{C}$ bond with the following 2 equiv being used for the formation of the ammonium salt.

Reactions with Metal Salts. When 1 in benzene or dichloromethane was treated stoichiometrically (1:1) with a variety of metal salts, including $\mathrm{SnMe}_{2} \mathrm{Br}_{2}, \mathrm{NiBr}_{2}\left(\mathrm{PBu}_{3}\right)_{2}$, $\mathrm{ZrCl}_{4}, \mathrm{PdCl}_{2}(\mathrm{NCPh})_{2}, \mathrm{HgCl}_{2}, \mathrm{PtBr}_{2}(\mathrm{COD})$, and [IrCl(COD) $]_{2}$, an irreversible transmetalation reaction occurred, and $[\mathrm{RhX} \text { (diene) }]_{2}$ and the corresponding $\mathrm{M}\left[\mathrm{C}_{6} \mathrm{H}_{3}\right.$ $\left.\left(\mathrm{CH}_{2} \mathrm{NMe}_{2}\right)_{2}-0,0^{\prime}\right]$ complexes were formed quantitatively in a $1: 2$ ratio (eq 7). No reaction was observed between

$$
\begin{aligned}
& \mathrm{Rh}^{\mathrm{I}}\left[\mathrm{C}_{6} \mathrm{H}_{3}\left(\mathrm{CH}_{2} \mathrm{NMe}_{2}\right)_{2}-0,0^{\prime}\right](\text { diene })+\mathrm{MX}_{n} \mathrm{~L}_{m} \rightarrow
\end{aligned}
$$

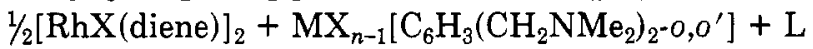

1 and $\mathrm{RhCl}_{3}, \mathrm{RhCl}_{3}\left(\mathrm{H}_{2} \mathrm{O}\right)_{3},[\mathrm{RhCl}(\mathrm{COD})]_{2}, \mathrm{IrCl}_{3}$, or $\mathrm{TaCl}_{5}$. Due to similarity in the solubilities of the rhodium(I) dimers and the $\mathrm{MX}\left[\mathrm{C}_{6} \mathrm{H}_{3}\left(\mathrm{CH}_{2} \mathrm{NMe}_{2}\right)_{2}-0,0^{\prime}\right]$ products, they could, in general, not be separated from each other. As with protic reagents, these reactions of 1 with metal salts clearly involve cleavage of the $\mathrm{Rh}-\mathrm{C}$ (aryl) bond. With the exception of $\mathrm{ZrCl}_{3}\left[\mathrm{C}_{6} \mathrm{H}_{3}\left(\mathrm{CH}_{2} \mathrm{NMe}_{2}\right)_{2}-0,0^{\prime}\right]^{11}$ and $\operatorname{Ir}\left[\mathrm{C}_{6} \mathrm{H}_{3^{-}}\right.$ $\left.\left(\mathrm{CH}_{2} \mathrm{NMe}_{2}\right)_{2}-0,0^{\prime}\right](\mathrm{COD}),{ }^{13}$ all reaction products $\mathrm{MX}$ $\left[\mathrm{C}_{6} \mathrm{H}_{3}\left(\mathrm{CH}_{2} \mathrm{NMe}_{2}\right)_{2}-0,0^{\prime}\right]$ had been prepared previously by independent routes and, therefore, could be identified by comparison of the ${ }^{1} \mathrm{H}$ NMR spectra of the mixtures with those of authentic samples.

The reaction of la with $\mathrm{Me}_{2} \mathrm{SnBr}_{2}$ is exceptional in that it forms a water-soluble salt, $\left\{\mathrm{SnMe}_{2}\left[\mathrm{C}_{6} \mathrm{H}_{3}\left(\mathrm{CH}_{2} \mathrm{NMe}_{2}\right)_{2}\right.\right.$ $\left.\left.0,0^{\prime}\right]\right\} \mathrm{Br},{ }^{1 \mathrm{~b}}$ that could be separated from $[\mathrm{RhBr}(\mathrm{COD})]_{2}$. Interestingly, this product could only be obtained if methanol or water was added to the apolar benzene solution. There is ${ }^{1} \mathrm{H}$ NMR evidence that the reaction of $1 \mathrm{a}$ with $\mathrm{SnMe} \mathrm{M}_{2} \mathrm{Br}_{2}$ proceeds via the initial formation of $\mathrm{SnMe}_{2} \mathrm{Br}\left[\mathrm{C}_{6} \mathrm{H}_{3}\left(\mathrm{CH}_{2} \mathrm{NMe}_{2}\right)_{2}-0,0^{\prime}\right]$ in which the aryl moiety is only bidentate $\mathrm{C}, \mathrm{N}$-coordinated. Subsequent addition of a polar solvent then initiates substitution of a bromide by the uncoordinated $\mathrm{CH}_{2} \mathrm{NMe}_{2}$ group, leading to the formation of the cation $\left\{\mathrm{SnMe}_{2}\left(\left[\mathrm{C}_{6} \mathrm{H}_{3}\left(\mathrm{CH}_{2} \mathrm{NMe}_{2}\right)_{2}-0,0^{\prime}\right]\right\} \mathrm{Br}\right.$. These steps are summarized in eq 8 .

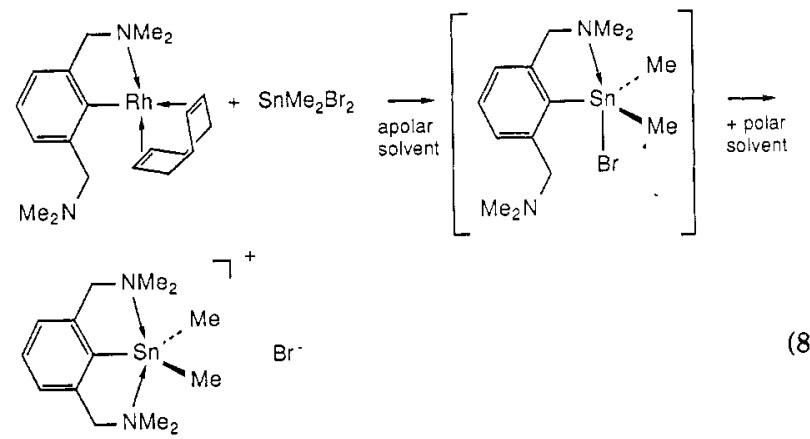

The transmetalation reaction of 1 with $[\operatorname{IrCl}(\mathrm{COD})]_{2}$ to form $\operatorname{Ir}\left[\mathrm{C}_{6} \mathrm{H}_{3}\left(\mathrm{CH}_{2} \mathrm{NMe}_{2}\right)_{2}-0,0^{\prime}\right](\mathrm{COD})$ is interesting because it is attended by the cleavage and then the formation of only one $\mathrm{M}-\mathrm{N}$ bond. An important conclusion that can be drawn from this reaction is that the steric crowding in 1 is not the driving force of the transmetalation, since it is likely to be just as severe in the isostructural iridium product. Thus, the role of steric crowding is, at most, to lower the kinetic barriers, with the reaction being driven by thermodynamics.

The reaction of 1 with silver salts follows a different course. Addition of 2 equiv of $\mathrm{AgX}$ to 1 resulted in the deposition of metallic silver affording, after addition of water, the known octahedral rhodium(III) complexes $\mathrm{RhX}_{2}\left[\mathrm{C}_{6} \mathrm{H}_{3}\left(\mathrm{CH}_{2} \mathrm{NMe}_{2}\right)_{2}-0,0^{\prime}\right]\left(\mathrm{H}_{2} \mathrm{O}\right)\left(\mathrm{X}=\mathrm{OAc} \text { and } \mathrm{NO}_{3}\right)^{\mathrm{Iv}}$ (eq 9 ). In contrast to the other reactions of 1 with metal

$$
\begin{array}{r}
\mathrm{Rh}\left[\mathrm{C}_{6} \mathrm{H}_{3}\left(\mathrm{CH}_{2} \mathrm{NMe}_{2}\right)_{2}-0,0^{\prime}\right](\text { diene }) \frac{1 . \mathrm{Ag} \mathrm{X}\left(\mathrm{X}=\mathrm{OAc}, \mathrm{NO}_{3}\right)}{2 . \mathrm{H}_{2} \mathrm{O}} \\
\mathrm{RhX}_{2}\left[\mathrm{C}_{6} \mathrm{H}_{3}\left(\mathrm{CH}_{2} \mathrm{NMe}_{2}\right)_{2}-0,0^{\prime}\right]\left(\mathrm{H}_{2} \mathrm{O}\right)
\end{array}
$$

salts described above, the present reaction seems to be the result of an initial metal-metal interaction leading to electron transfer. Interactions of this type have been found in reactions of cis- and trans- $\mathrm{Pt}^{\mathrm{I}}\left[\mathrm{C}_{6} \mathrm{H}_{4}\left(\mathrm{CH}_{2} \mathrm{NMe}_{2}\right)-o\right]_{2}$ with $\mathrm{Hg}(\mathrm{OAc})_{2}$ : the cis congener yields a stable acetato-bridged $\mathrm{Pt}-\mathrm{Hg}$ compound while the trans congener in a redox reaction yields $\mathrm{Pt}^{\mathrm{NV}}\left[\mathrm{C}_{6} \mathrm{H}_{4}\left(\mathrm{CH}_{2} \mathrm{NMe}_{2}\right)-\mathrm{O}\right]_{2}(\mathrm{OAc})_{2} \cdot{ }^{1 \mathrm{c}}$ Although 
the reaction of 1 with $\mathrm{AgX}$ probably involves a rhodium(II) intermediate, this could not be isolated, addition of only 1 equiv of $\mathrm{AgX}$ yielding a half the amount of the rhodium(III) product. The ternary silver salts $\mathrm{AgCrO}_{4}$ and $\mathrm{Ag}_{2} \mathrm{SO}_{4}$ show no reaction with 1 .

Reaction with $\mathbf{H}_{2}$. When hydrogen is bubbled through a solution of 1 in benzene, a rapid and complete reduction of the complex results affording $m-\left(\mathrm{Me}_{2} \mathrm{NCH}_{2}\right)_{2} \mathrm{C}_{6} \mathrm{H}_{4}$, cyclooctane/norbornane, and, considering the blackening of the reaction mixture, probably metallic rhodium (eq 10).

$$
\mathrm{Rh}\left[\mathrm{C}_{6} \mathrm{H}_{3}\left(\mathrm{CH}_{2} \mathrm{NMe}_{2}\right)_{2}-o, o^{\prime}\right] \text { (diene) }+2^{1} /{ }_{2} \mathrm{H}_{2} \rightarrow
$$$$
\mathrm{Rh}+m \cdot\left(\mathrm{Me}_{2} \mathrm{NCH}_{2}\right)_{2} \mathrm{C}_{6} \mathrm{H}_{4}+\text { alkane (10) }
$$

Although the hydrogenation of the diolefin points to the presence of rhodium(III) dihydride olefin complexes in the intermediate steps, it is not known at which stage the olefins and the $\mathrm{Rh}-\mathrm{C}$ (aryl) bond are hydrogenated. Possible intermediates like $\mathrm{Rh}^{\mathrm{II}} \mathrm{H}_{2}\left[\mathrm{C}_{6} \mathrm{H}_{3}\left(\mathrm{CH}_{2} \mathrm{NMe}_{2}\right)_{2}-0,0^{\prime}\right]$ or $\left[\mathrm{Rh}^{\mathrm{I}} \mathrm{H} \text { (diene) }\right]_{4}{ }^{15 \mathrm{a}}$ were not observed, although an analogue of the former, $\mathrm{Rh}(\mathrm{H}) \mathrm{Cl}\left[\mathrm{C}_{6} \mathrm{H}_{3}\left(\mathrm{CH}_{2} \mathrm{P}(t-\mathrm{Bu})_{2}\right)_{2}\right]$, does exist. ${ }^{4 \mathrm{a}}$ Excess olefin, added to solutions of 1 , was not catalytically reduced by hydrogen in this reaction.

\section{Summary and Conclusions}

The use of "built-in" ligands in organic groups of the type $\left[\mathrm{C}_{6} \mathrm{H}_{3}\left(\mathrm{CH}_{2} \mathrm{NMe}_{2}\right)\right.$-o-R-o'] has been proven successful for the isolation of stable arylrhodium(I) compounds. The $\mathrm{C}, \mathrm{N}$-coordination of these organic ligands and hence the reactivity of $\mathrm{Rh}\left[\mathrm{C}_{6} \mathrm{H}_{3}\left(\mathrm{CH}_{2} \mathrm{NMe}_{2}\right)-0-\mathrm{R}-\mathrm{o}^{\prime}\right]$ (diene) is determined by the steric bulk of the ortho'-positioned alkyl group. When $\mathrm{R}$ is $\mathrm{CH}_{2} \mathrm{NMe}_{2}$ (1) and $\mathrm{Me}(2)$, the dissociation of the Rh-N bond and generation of a T-shaped 14-electron species accounts for the enhanced reactivity of 1 and 2 , with respect to $3(\mathrm{R}=\mathrm{H})$. It seems that the reactivity displayed by 1 toward electrophilic reagents, such as acids and metal salts, is dominated by the intermediacy of such a 14-electron species and not by the nu- cleophilic 16-electron template.

Acknowledgment. The investigation was supported in part (A.L.S. and B.K.P.) by the Netherlands Foundation for Chemical Research (S.O.N.) with financial aid from the Netherlands Organization for Advancement of Pure Research (Z.W.O.). The X-ray data were collected by Dr. A. J. M. Duisenberg. Professor K. Vrieze is thanked for helpful discussions.

Registry No. 1a, 115338-66-4; 1b, 115338-69-7; 2, 115338-67-5; 3, 115338-68-6; $\mathrm{Li}_{2}\left[\mathrm{C}_{6} \mathrm{H}_{3}\left(\mathrm{CH}_{2} \mathrm{NMe}_{2}\right)_{2}-0,0^{\prime}\right]_{2}, 82622-01-3$; [RhCl(COD) $]_{2}, \quad 12092-47-6 ; \quad[\mathrm{RhCl}(\mathrm{NBD})]_{2}, \quad 12257-42-0 ; \quad o$ $\left(\mathrm{Me}_{2} \mathrm{NCH}_{2}\right)$-o'-( $\mathrm{Me}_{6} \mathrm{C}_{6} \mathrm{H}_{3} \mathrm{Br}, 114739-32-1 ; \mathrm{Li}_{6}\left[\mathrm{C}_{6} \mathrm{H}_{4}\left(\mathrm{CH}_{2} \mathrm{NMe}_{2}\right)\right.$-o], 60528-57-6; [m-( $\left.\left.\mathrm{Me}_{2}(\mathrm{H}) \mathrm{NCH}_{2}\right)_{2} \mathrm{C}_{6} \mathrm{H}_{4}\right] \mathrm{Cl}_{2}, 63400-16-8$; [m-( $\mathrm{Me}_{2}$ (H) $\left.\left.\mathrm{NCH}_{2}\right)_{2} \mathrm{C}_{6} \mathrm{H}_{4}\right] \mathrm{Br}, 115338-75-5$; [RhBr(COD) $]_{2}, 12092-45-4$; $[\mathrm{RhOAc}(\mathrm{COD})]_{2}, 12097-36-8 ;\left[m-\left(\mathrm{Me}_{2}(\mathrm{H}) \mathrm{NCH}_{2}\right)_{2} \mathrm{C}_{6} \mathrm{H}_{4}\right] \mathrm{OAc} \mathrm{C}_{2}$, 115338-76-6; [RhOMe(COD) ] $2,12148-72-0 ; m-\left(\mathrm{Me}_{2} \mathrm{NCH}_{2}\right)_{2} \mathrm{C}_{6} \mathrm{H}_{4}$, 19851-44-6; Rh(acac) (COD), 12245-39-5; [RhOH(COD) ] 2,73468 85-6; [Rh(L-alanyl)(COD) $]_{2}, 115338-70-0 ; \quad\left[\mathrm{SnMe}_{2}\left[\mathrm{C}_{6} \mathrm{H}_{3}\right.\right.$ $\left.\left(\mathrm{CH}_{2} \mathrm{NMe}_{2}\right)_{2}-0, o^{\prime}\right] \mathrm{Br}, 66484-01-3 ; \mathrm{NiBr}_{2}\left(\mathrm{PBu}_{3}\right)_{2}, 15242-92-9 ; \mathrm{ZrCl}_{4}$ 10026-11-6; $\mathrm{PdCl}_{2}(\mathrm{NCPh})_{2}, 14220-64-5 ; \mathrm{HgCl}_{2}, 7487-94-7$; [ $\mathrm{IrCl}-$ (COD) $]_{2}, 12112-67-3 ; \mathrm{PtBr}_{2}$ (COD), 12145-48-1; $\mathrm{NiBr}\left[\mathrm{C}_{6} \mathrm{H}_{3}\right.$ $\left.\left(\mathrm{CH}_{2} \mathrm{NMe}_{2}\right)_{2}-0,0^{\prime}\right], 84500-93-6 ; \mathrm{ZrCl}_{3}\left[\mathrm{C}_{6} \mathrm{H}_{3}\left(\mathrm{CH}_{2} \mathrm{NMe}_{2}\right)_{2-0,0^{\prime}}\right]$, 115338-71-1; $\mathrm{PdCl}\left[\mathrm{C}_{6} \mathrm{H}_{3}\left(\mathrm{CH}_{2} \mathrm{NMe}_{2}\right)_{2}-0, o^{\prime}\right], 82112-98-9 ; \mathrm{HgCl}-$ $\left[\mathrm{C}_{6} \mathrm{H}_{3}\left(\mathrm{CH}_{2} \mathrm{NMe}_{2}\right)_{2}-0,0^{\prime}\right], 81352-52-5 ; \mathrm{PtBr}\left[\mathrm{C}_{6} \mathrm{H}_{3}\left(\mathrm{CH}_{2} \mathrm{NMe}_{2}\right)_{2}-0,0^{\prime}\right]$, 67507-09-9; $\operatorname{Ir}\left[\mathrm{C}_{6} \mathrm{H}_{3}\left(\mathrm{CH}_{2} \mathrm{NMe}_{2}\right)_{2}-0,0^{\prime}\right], 114762-89-9 ; \mathrm{RhCl}_{3-}$ $\left[\mathrm{C}_{6} \mathrm{H}_{3}\left(\mathrm{CH}_{2} \mathrm{NMe}_{2}\right)_{2}-0, o^{\prime}\right], 10049-07-7 ; \mathrm{RhCl}_{3}\left(\mathrm{H}_{2} \mathrm{O}\right)_{3}, 13569-65-8$; $\mathrm{IrCl}_{3}, \quad 10025-83-9 ; \mathrm{TaCl}_{5}, \quad 7721-01-9 ; \quad \mathrm{Rh}(\mathrm{OAc})_{2}\left[\mathrm{C}_{6} \mathrm{H}_{3}\right.$ $\left.\left(\mathrm{CH}_{2} \mathrm{NMe}_{2}\right)_{2}-0,0^{\prime}\right]\left(\mathrm{H}_{2} \mathrm{O}\right), \quad 112596-43-7 ; \quad \mathrm{Rh}\left(\mathrm{NO}_{3}\right)_{2}\left[\mathrm{C}_{6} \mathrm{H}_{3}-\right.$ $\left.\left(\mathrm{CH}_{2} \mathrm{NMe}_{2}\right)_{2}-0,0^{\prime}\right]\left(\mathrm{H}_{2} \mathrm{O}\right), 112596-44-8 ; \mathrm{Rh}\left[\mathrm{C}_{6} \mathrm{H}_{3}\left(\mathrm{CH}_{2} \mathrm{NMe}_{2}\right)_{2-0,-}\right.$ $\left.o^{\prime}\right](\mathrm{COD})(\mathrm{CO}), 115338-72-2 ; \mathrm{Rh}\left[\mathrm{C}_{6} \mathrm{H}_{3}\left(\mathrm{CH}_{2} \mathrm{NMe}_{2}\right)_{2}-0, o^{\prime}\right](\mathrm{COD})-$ $\left(\mathrm{PPh}_{3}\right), 115338-73-3 ; \mathrm{Rh}\left[\mathrm{C}_{6} \mathrm{H}_{3}\left(\mathrm{CH}_{2} \mathrm{NMe}_{2}\right)_{2}-0,0^{\prime}\right](\mathrm{COD})(\mathrm{PhC} \equiv$ $\mathrm{CPh}$, 115338-74-4; Rh, 7440-16-6; norbornane, 279-23-2; cyclooctane, 292-64-8.

Supplementary Material Available: Tables of all refined parameters and complete listings of bond lengths and bond angles (7 pages); a listing of observed and calculated structure factors (36 pages). Ordering information is given on any current masthead page. 